\title{
MELLÁR TAMÁS-NÉMETH KRISTÓF
}

\section{A kibocsátási rés becslése többváltozós állapottérmodellekben}

\author{
Szuperhiszterézis és további empirikus eredmények
}

\begin{abstract}
A reál-GDP ciklikus komponensének megbízható becslése különösen fontos a gazdaságpolitika számára. A kibocsátási rés különböző típusú modellekből kapott értékei olykor jelentősen eltérő, akár egymásnak ellentmondó képet mutatnak a konjunktúra alakulásáról. Mivel a hagyományos eljárások (HP-szürő, termelési függvény) nem képesek megragadni a makrogazdasági egyensúly komplex, többdimenziós jellegét, ezért a kibocsátási rés becslésének több lehetséges módszerét ismertetjük, kiemelve a többváltozós megközelítéseket. Azt vizsgáljuk, hogy a többváltozós állapottér-modellek mennyiben használhatók a magyar gazdaság ciklikus pozíciójának értékelésére. Mivel az egyes modellekben eltérö módon ragadható meg a többváltozós makrogazdasági egyensúly, az eredmények bizonyos időszakokban komoly eltéréseket mutatnak. A különböző modellekből származó becslések összevetése ugyanakkor hasznos tanulságokkal szolgálhat. Eredményeink alapján három lényegi következtetésre jutunk: 1. a pozitív rés elsősorban nem a válságot közvetlenül megelőző években alakult ki, hanem 2004 és 2006 között; 2. 2016 végére a negatív kibocsátási rés bezárult; 3. a gazdaság növekedési képessége a válságot követően tartósan és jelentősen csökkent. A potenciális növekedés korábbi, évi 4 százalékos üteme a felére esett a vizsgált periódusban.* Journal of Economic Literature (JEL) kód: C32, C51, E66.
\end{abstract}

A potenciális kibocsátás $(\bar{Y})$ és a hozzá kapcsolódó kibocsátási rés $(\hat{Y})$ minden bizonnyal az elmúlt két évtized meghatározó kategóriái között szerepelnek a makroökonómiában és kiváltképpen a gazdaságpolitikai elemzésekben. A népszerüség magyarázata elég kézenfekvő, hiszen a potenciális kibocsátás a GDP egyensúlyi pályájának tekinthető,

* A szerzők mindenekelőtt köszönetet mondanak a tanulmány lektorának, akinek hasznos, építő jellegü bírálatai sokat segítettek abban, hogy a tanulmány elnyerje jelenlegi formáját. Köszönettel tartozunk továbbá Abaligeti Gallusznak, Balatoni Andrásnak, Czelleng Ádámnak, Kehl Dánielnek, Komlósi Sándornak, Kónya Istvánnak, Oroszvári Dávidnak, Rácz Olivérnek, Rappai Gábornak, Reiff Ádámnak, Schepp Zoltánnak, Tóth Máténak, Várpalotai Viktornak, Váry Miklósnak és Világi Balázsnak munkánk előremozdításáért. Köszönet illeti a Pallas Athéné Domus Educationis Alapítványt szakmai és anyagi támogatásáért.

Mellár Tamás egyetemi tanár, PTE Közgazdaságtudományi Kar (e-mail: mellart@ktk.pte.hu). Németh Kristóf doktorjelölt, PTE Közgazdaságtudományi Kar, Regionális Politika és Gazdaságtan

Doktori Iskola (e-mail: nemethkf@ktk.pte.hu).

A kézirat első változata 2017. május 29-én érkezett szerkesztőségünkbe.

DOI: http://dx.doi.org/10.18414/KSZ.2018.6.557 
s mint ilyen, jelentősége kivételes. A tényleges és a potenciális kibocsátás százalékos eltérése, a kibocsátási rés (output gap) a makrogazdasági egyensúly egyik legfontosabb mutatója, mivel az általános konjunkturális helyzetet jellemzi, konkrét információkat szolgáltat a keresleti nyomás aktuális értékére vonatkozóan. ${ }^{1}$ Erre az információra támaszkodnak a gazdaságpolitika irányítói is, amikor a gazdaságpolitikai stratégiáikat megtervezik, illetve amikor a kiváltott hatásokat mérik fel. Az általánosan elterjedt inflációscél-követési politika kifejezetten épít a kibocsátási rés becslésére, mivel a jegybanki alapkamat meghatározási szabálya (jellemzően egy Taylor-típusú endogén szabály) magyarázó változóként szerepelteti a kibocsátási rés múltbeli vagy egyidejü becsült értékét (Abaligeti és szerzőtársai [2018], Taylor [1993]).

Tanulmányunk általános megállapításait, a becslési eredmények értékelését meghatározza az a tény, hogy a potenciális kibocsátás és a kibocsátási rés nem megfigyelhetö, látens változók. Így azok tényleges értékét sem megfigyelés, sem adatgyüjtés által nem lehet meghatározni. Az említett változók legjobb, optimális becslését keresni tehát túlzottan is ambiciózus vállalkozás volna. A különböző kibocsátásirésbecsléseket illetően több értékelési kritérium létezik, amelyek lényegében a becslések inflációs nyomást előrejelző erejét számszerüsítik (Rácz [2012]). Létezik továbbá egy mindenkori, többé-kevésbé általános szakmai közvélekedés (anecdotal evidence) is, amelynek megerősítését önkéntelenül is elvárhatjuk a becslésektől. Az egyik esetben a Phillips-görbe-összefüggés jelentős gyengülése, míg a másikban a modellezői prekoncepciók horgonyzó ereje jelenthet problémát (Borio és szerzötársai [2017], Canova [1998b]). Tanulmányunk célja a különböző modellépítési eljárások bemutatása és azok eredményeinek összehasonlító elemzése. Úgy gondoljuk, hogy a magyar gazdaság teljesítménye szempontjából meghatározó gazdasági ciklus azonosítására, illetve dokumentálásra tett kísérlet leginkább a különbözö becslési eredmények összehasonlító elemzésével lehet eredményes (Canova [1998a]).

A kibocsátási rés és a potenciális kibocsátás becslése szempontjából négy, egymással szorosan összefüggő kérdés merül fel:

1. Milyen elméleti vagy empirikus szempontból releváns összefüggésekre építünk a modellspecifikáció során?

2. Hogyan becsüljük a potenciális kibocsátás és a kibocsátási rés értékét?

3. Hogyan értelmezhető makrogazdasági szempontból az az egyensúly, amelyet a becsült potenciális pálya meghatároz?

4. A kibocsátási résre vonatkozó becslés milyen ütemü potenciális növekedést implikál a vizsgált időszakban?

Tanulmányunk elején tisztázzuk, hogy saját modelljeinkben a reál-GDP trendrés-felbontását ökonometriai modellek segítségével végezzük el. Mindenekelött feltételezzük a nem megfigyelhető trend- és réskomponensek létezést, majd azokat statisztikai értelemben eltérő tulajdonságokkal ruházzuk fel. A trend- és a ciklikus komponensek alapulhatnak például a komponensek relatív volatilitására vagy

\footnotetext{
${ }^{1}$ A kibocsátási rés a tényleges (aktuális) kibocsátásnak a potenciális szinttől vett százalékos eltérését jelöli: $\hat{Y}_{t} \equiv\left(Y_{t}-\bar{Y}_{t}\right) / \bar{Y}_{t} \approx \log Y_{t}-\log \bar{Y}_{t}$. A változók logaritmusát kisbetűvel jelölve: $\hat{Y}_{t} \approx y_{t}-\bar{y}_{t}$.
} 
azok különböző fokú integráltságára vonatkozó feltevésen. Ebben az értelmezésben a potenciális kibocsátás a trendértékeket jelöli, a kibocsátási rés pedig a tényidősor trendtől vett százalékos eltérését mutatja.

A potenciális kibocsátás megszokott elméleti értelmezése szerint azt a kibocsátási szintet jelöli, amely nominális merevségek hiányában, vagyis rugalmas ár- és béralkalmazkodás mellett megvalósulna (Galí [2015]). Ebben az elméleti keretben a kibocsátási rés csak a nominális merevségek miatt létezik, és azok jelentőségét hivatott számszerüsíteni. Tanulmányunkban ehhez képest a kibocsátási rés a makroszintü egyensúlytalanságok általános mérőszámaként, indikátoraként jelenik meg. Az alábbiakban azt vizsgáljuk, hogy a különböző modellekben a kibocsátási rés becsült értékei vajon mennyiben felelnek meg ennek a funkciónak?

A tanulmány szerkezete a következö. Először áttekintjük a kibocsátási rés becslésének hagyományos módszereit. Ezt követően egy olyan állapottérmodellt vizsgálunk, amelyben a kibocsátási rés állapotegyenletét közvetlen módon exogén magyarázó változókkal egészítjük ki. Majd egy többváltozós kvázistrukturális trend-rés-felbontás eredményét értékeljük, és összehasonlító elemzésünket a Magyar Nemzeti Bank (MNB) kibocsátásirés-becslésével vetjük össze (MNB [2017]). Ezek után fogalmazzuk meg tanulmányunk következtetéseit.

\section{Hagyományos eljárások}

Tanulmányunkban különböző becslési eljárásokat bemutatva igyekszünk választ adni a bevezetésben megfogalmazott kutatási kérdésekre. Elöször két, széles körben alkalmazott, hagyományosnak mondható eljárást mutatunk be.

\section{A Hodrick-Prescott-szürön alapuló becslés}

A potenciális kibocsátás adott időszaki értékének meghatározásához több lehetséges eljárás közül is választhatunk. Ezek közül elsőként a potenciális kibocsátás trendszámításon alapuló becslését ismertetjük. Ez a viszonylag egyszerű módszer azon az empirikus tényen (intuíción) alapul, hogy a potenciális kibocsátás egy viszonylag simán viselkedő idősor, amelynek ingadozásai kisebbek, mint a tényleges kibocsátáséi. A gyakorlatban igen sürün lehet találkozni ezzel a megoldással, amikor is a potenciális pályát a GDP trendértékeinek idősorával közelítik. A leggyakrabban használt egyváltozós szürő Hodrick és Prescott (HP) nevéhez füződik (Hodrick-Prescott [1997]). A HP-szürőben az (1) minimumfeladat megoldásaként adódik a trendértékek $(\bar{Y})$ idősora, vagyis a potenciális pálya: ${ }^{2}$

$\min _{\bar{Y}_{t}}\left\{\sum_{t=1}^{T}\left(Y_{t}-\bar{Y}_{t}\right)^{2}+\lambda \sum_{t=2}^{T-1}\left[\left(\bar{Y}_{t+1}-\bar{Y}_{t}\right)-\left(\bar{Y}_{t}-\bar{Y}_{t-1}\right)\right]\right\}$.

\footnotetext{
${ }^{2}$ A képletek jelöléseit lásd a Függelék F1. táblázatában.
} 
Mivel a trendillesztés logikájából adódóan a trendkomponensek és a ciklikus komponensek kölcsönös meghatározottságban állnak egymással, így a becslés semmilyen formában sem épít a közgazdaságtani elmélet releváns összefüggéseire (Canova [2007]).

A kibocsátási rés $(\hat{Y})$ adott időszaki értéke a tényleges idősori érték és a trendkomponens ismeretében az alábbi módon számítható ki:

$\hat{Y}_{t} \equiv \frac{Y_{t}-\bar{Y}_{t}}{\bar{Y}_{t}} \approx \log Y_{t}-\log \bar{Y}_{t}$.

A frekvenciatartományon alapuló idősori elemzések (a spektrálanalízis) terminológiáját követve azt mondhatjuk, hogy a HP-szürő használatával egy általunk választott frekvenciatartományhoz tartozó idősori komponenseket (hullámokat) kiszürjük az idősorból (Greene [2011], Pintér [2007]). Ezt a frekvenciatartományt jelöljük ki $\lambda$ paraméter értékének megválasztásával (Harvey-Jaeger [1993]). A kibocsátási rés idősora ennek megfelelően a nagyobb frekvenciájú, gyorsabb lefolyású, jellemzően a reálgazdasági ciklusokat (Real Business Cycle, $R B C$ ) hivatott ábrázolni, míg a trendben csak az alacsonyabb frekvenciájú, vagyis lassabb lefolyású ciklusok okozhatnak változást (Canova [2007], Hodrick-Prescott [1997]).

A fenti eljárás működéséből adódó probléma, hogy a vizsgált időszak végén lévő trendforduló azonosítása különösen is nehézzé válik. Ezt a problémát végponti gyengeségnek, ritkábban végeffektusnak nevezzük, ami minden szimmetrikus - az időben egyszerre előre- és hátratekintő - szürő alkalmazásakor nehézséget okoz (Canova [2007]). Az eljárás további hiányosságai mellett tehát még ezzel a járulékos bizonytalansággal is számolnunk kell. Következésképpen, az egyváltozós HP-szürőre alapozott kibocsátásirés-becslés nem adhat megbízható képet sem a jelenlegi egyensúlytalansági viszonyokról, sem a reál-GDP közeljövőben várható viselkedéséről (Benk és szerzőtársai [2005], Hamilton [2017]).

Az 1. ábra a hazai reál-GDP negyedéves idősorának ciklikus komponensét mutatja $\lambda=1600$ paraméterérték mellett, teljes mintán végzett HP-simítás után. ${ }^{3}$ A HP-simítás eredményének bemutatása előtt tisztázzuk, hogy miként értelmezzük a nem megfigyelt ciklikus komponens $(\hat{Y})$ becslését. Ezek szerint a különböző modellbecslések eredménye minden esetben a szóban forgó látens változó (állapotváltozó) simított becslését jelöli. Fix intervallumú simítást alkalmazunk, ahol a simítási periódus vége megegyezik az adott becsléshez használt minta végpontjával (Durbin-Koopman [2012] 4.4. alfejezet, Harvey [1990] 3.6. alfejezet). Miután a ciklikus komponens filterezett és simított értékének megkülönböztetésére nincs szükség, ezért a továbbiakban egyszerüen csak becslési eredményekröl beszélünk. Továbbá, ahol az a szövegkörnyezet alapján kézenfekvő, ott a szürés kifejezéssel a trend-rés-felbontás mint statisztikai eljárás egészére hivatkozunk. Mindemellett, a különböző modellek specifikációja, illetve becslése során következetesen eltekintünk az esetleges mérési hibák szerepétől. Az irodalomban látott gyakorlatot követve azt feltételezzük tehát, hogy a külön-

\footnotetext{
${ }^{3}$ A bruttó hazai termék (GDP) termelése 2005. évi átlagáron, szezonálisan és naptári hatással kiigazított és kiegyensúlyozott adatok (http://www.ksh.hu/docs/hun/xstadat/xstadat_evkozi/e_qpt007a.html).
} 
böző makroidősorokat illetően a trend- és a ciklikus komponensek összege minden időszakban a tényleges idősori értéket vagy annak logaritmusát eredményezi (Borio és szerzőtársai [2014], Canova [1998a]). Kivétel ez alól a későbbiekben vizsgált (16) megfigyelési egyenlet, amely az infláció trendértékét igyekszik az MNB által meghirdetett inflációs cél közelében rögzíteni [lásd a (16) egyenlet véletlen tagját $\left(\epsilon_{t}^{T}\right)$ ].

\section{1. ábra}

A kibocsátási rés HP-simítással adódó becslése, 2002. I. negyedév-2016. IV. negyedév $(\lambda=1600$ paraméterérték mellett)

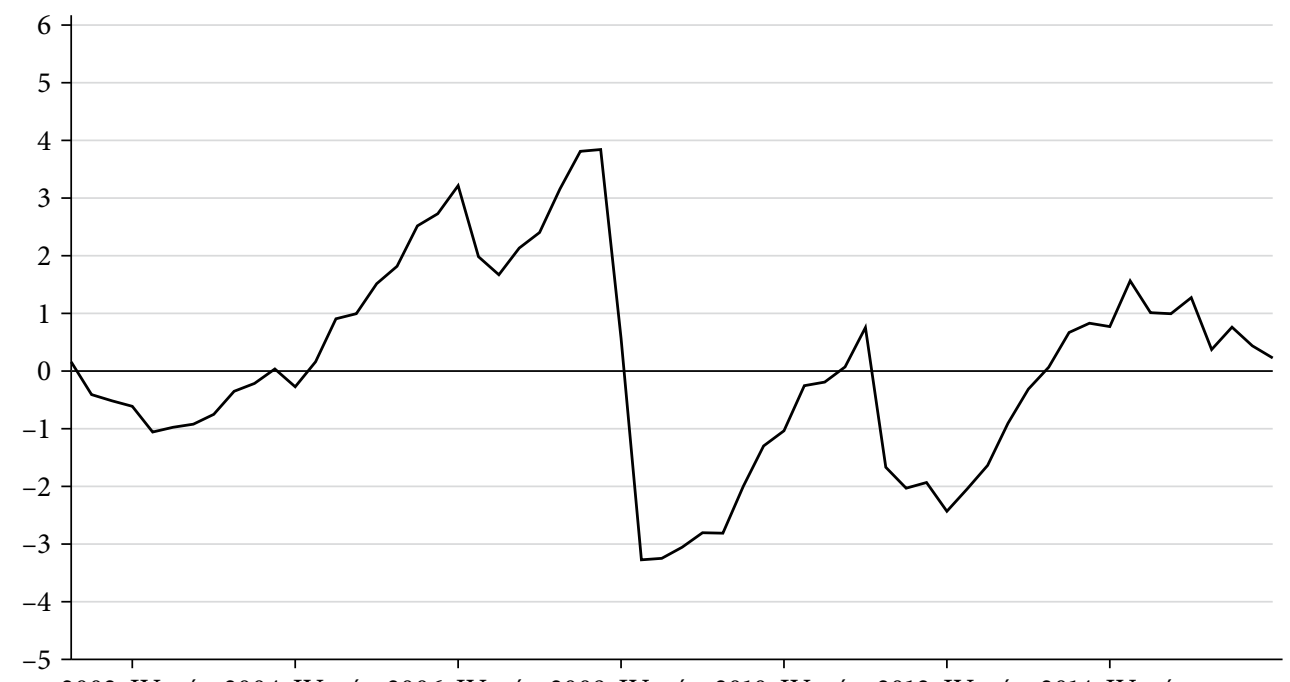

2002. IV. né. 2004. IV. né. 2006. IV. né. 2008. IV. né. 2010. IV. né. 2012. IV. né. 2014. IV. né.

Forrás: saját szerkesztés.

A különböző becslési eredmények összehasonlíthatóságát szem előtt tartva, a saját számítások eredményét csak abban az időszakban ábrázoltuk, amelyben az MNB becslésének eredménye is „látható”. Mivel tanulmányunk lezárásakor a 2017. márciusi inflációs jelentés volt aktuális (MNB [2017]), ez az időszak 2002 első negyedévétől 2016 utolsó negyedévéig terjed. ${ }^{4}$ Ezzel együtt minden esetben az elérhető legnagyobb minta mellett végeztük el a becslést: a HP-simítás esetében a simítási intervallum 1995 első negyedévétől 2016 utolsó negyedévéig terjed, az eredményeket pedig 2002 első negyedévétől 2016 negyedik negyedévéig ábrázoljuk.

$\mathrm{Az}$ 1. ábra értelmezésekor mindenekelőtt látnunk kell, hogy a HP-simításra alapozott becslés semmiben sem épít a makroökonómiai elmélet releváns összefüggéseire. Egy egyszerü idősoros technikát alkalmazunk, amely azon a statisztikai feltételezésen alapul, hogy a trend kevésbé volatilis, mint a tényleges idősor. Ez az intuitív feltevés (stilizált tény) a fenti (1)-es képletben úgy jelenik meg, hogy a $\lambda$ paraméterrel „büntetjük”

\footnotetext{
${ }^{4}$ Tanulmányunk lényegi következtetései szempontjából egyébként is másodlagos fontosságú a 2002 előtti időszak vizsgálata.
} 
a trend gyorsulását. Előzőleg azt is láttuk, hogy az eljárás működéséből adódóan az 1. ábrán látható trend-rés-felbontást erős végponti bizonytalanság jellemzi.

A kibocsátási rés értékeinek idősorát tekintve azt mondhatnánk, hogy a pozitív kibocsátási rés elsődlegesen a 2008. évi válságot megelőző két évben alakult ki: 2007 közepétől 2008 végéig. Úgy gondoljuk, ez egy alapvetően téves interpretáció, hiszen 2007 már egy kimondottan gyenge év volt a gazdasági növekedés szempontjából (fél százalék körüli reálbővüléssel). Ezzel együtt sem mondanánk, hogy a HP-simítás 1. ábrán látott eredménye teljes egészében ellentmond azon kutatási hipotézisünknek, hogy a pozitív rés főként a 2004 és 2006 közötti időszakra tehető. Az 1. ábrán ugyanis jól látszik a kibocsátási rés 2004 végétől 2006 végéig terjedő felfutása: a kibocsátási rés értéke a kezdeti nullához közeli szintről 3 százalékra nőtt az említett időszakban. Mindazonáltal a legnagyobb becsült értékeket közvetlenül a pénzügyi válság hazai begyürüzését megelőző negyedévekben látjuk: 2008 második és harmadik negyedévében közel 4 százalékos pozitív rést.

A fentiek láttán természetesen az is megkérdőjelezhető, hogy a HP-simítás negatív kibocsátási rést mutat 2002 és 2004 között. Az elérhető makroadatok elég egyértelmüen azt jelzik, hogy a gazdaságpolitikák már akkor túlhajtották a növekedés ösztönzését: ekkor kezdett kialakulni a tartósan magas államháztartási hiány, az államadósság meredek emelkedése, valamint a külkereskedelmi és fizetési mérlegek nagymértékü hiánya.

A 2008. évi válságot megelőző évek felelőtlen költségvetési politikáját találóan jellemzi Kopits György, aki „fiskális alkoholizmustól” szenvedő kormányokról ír (Kopits [2006], [2008]). A válság utáni időszakot tekintve úgy gondoljuk, hogy a HP-simítás

\section{2. ábra}

A tényleges és a HP-simítás eredménye alapján kalkulált éves potenciális növekedés, 2003. I. negyedév-2016. IV. negyedév

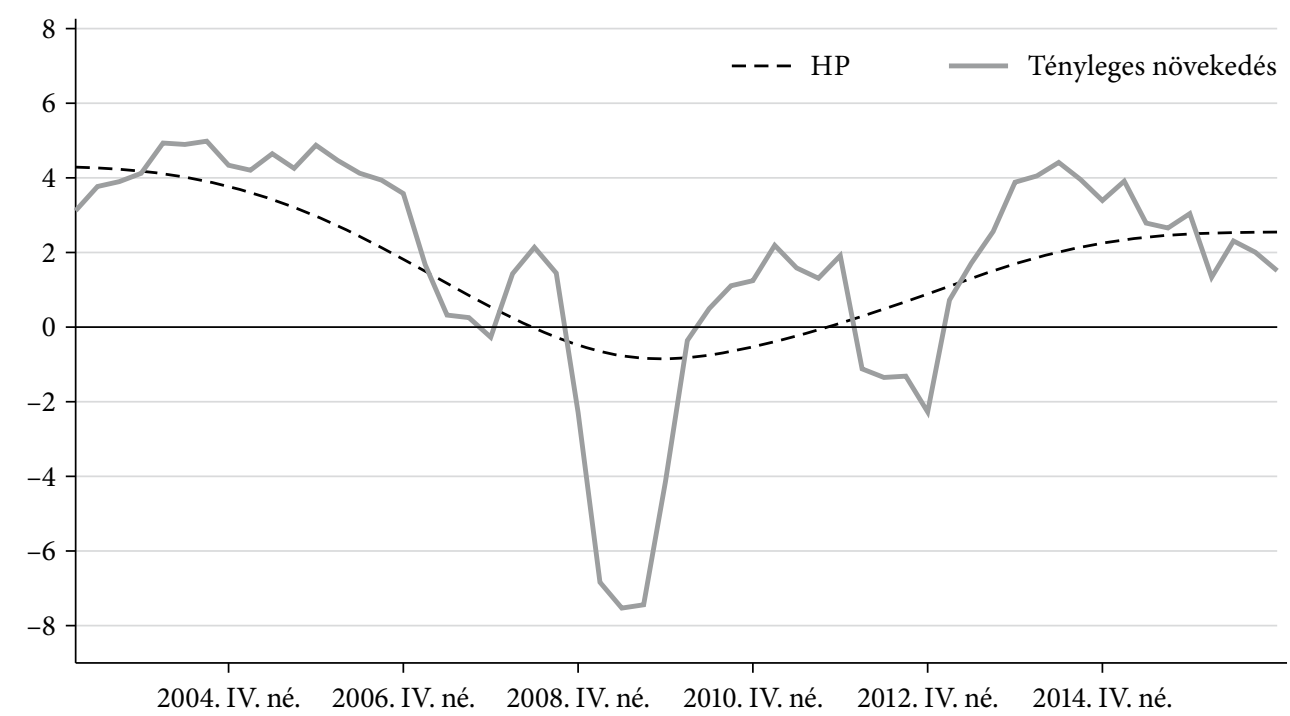

Forrás: saját szerkesztés. 
eredménye alapvetően jól jellemzi a válság utáni helyreállítás megtorpanását 20112012-ben. Az természetesen további elemzések tárgya lehet, hogy vajon zárult-e teljesen már akkor a negatív kibocsátási rés. Az 1. ábra tanúsága szerint a kibocsátási rés 2014-től már pozitív: némi emelkedés után 2016 végére nullához közeli értéket kapunk. Az eljárás nagymértékü végponti bizonytalanságát szem előtt tartva, ezt az eredményt különös óvatossággal értékeljük.

Egy kibocsátási rés becslésének az értékelésekor kulcsfontosságú, hogy az adott becslés milyen potenciális pályát, illetve milyen ütemü (éves) potenciális növekedést implikál a vizsgált időszakra. A 2. ábrán szürke folytonos vonal jelöli a reál-GDP tényleges éves (előző év azonos negyedévéhez mért) százalékos növekedési ütemét, míg a fekete szaggatott vonal a HP-szürés (simítás) eredménye alapján kalkulált potenciális növekedési ütemek idősorát jelöli.

A 2. ábra azt mutatja, hogy a HP-simítással számított potenciális növekedési pálya több mint évi 4 százalékos potenciális növekedési ütemet jelez 2003 elején. Ettől kezdve a potenciális növekedési ütem fokozatos lassulását láthatjuk. A trend újbóli gyorsulása 2010 elejétől figyelhető meg, éves növekedése ugyanakkor még a vizsgált időszak végén is elmarad a kezdeti 4 százalékos értéktől. A 2. ábra alapján azt mondhatjuk tehát, hogy a magyar gazdaság éves potenciális növekedése számottevően és tartósan lecsökkent a 2008. évi válság után: a korábbi 4 százalékos potenciális növekedési ütem 2016 végére 2,5 százalékra mérséklődött.

\section{Termelési függvényen alapuló eljárás}

Az elöbb látott, trendillesztésen alapuló megközelítést nem nevezzük strukturálisnak, mivel semmilyen formában sem épít a makrogazdaság működését leíró elméleti összefüggésekre. Ehhez képest a termelési függvényre építö, elméleti megalapozottságú eljárás esetén a potenciális kibocsátás az output azon szintjét jelöli, amely nem okoz keresletoldali inflációs nyomást, vagyis megfelel a kínálati oldalról meghatározott kibocsátási szintnek (Mankiw [1999], Mellár [2008]). Ezt az elméleti összefüggést használjuk fel akkor, amikor az egyensúlyi pálya meghatározásának termelésifüggvény-alapú megközelítését alkalmazzuk. Egy kínálati oldalról meghatározott gazdaságban ugyanis a potenciális kibocsátást - a klasszikus modell szerint - a munka- és tőkeráfordításokat felhasználó termelési függvény határozza meg (D’Auria és szerzötársai [2010], Endrész és szerzőtársai [2012], Giorno és szerzőtársai [1995], Mellár [2011]). Ez alapján a potenciális kibocsátás értéke $(\bar{Y})$ egy Cobb-Douglas-típusú termelési függvényben az alábbiak szerint határozható meg:

$\bar{Y}_{t}=\bar{A}_{t} K_{t}^{\alpha}\left[\bar{L}_{t}\left(1-\frac{N A I R U}{100}\right)\right]^{1-\alpha}$,

ahol $A_{t}$ a teljes tényezőtermelékenységet (Solow-féle reziduum), $K_{t}$ és $L_{t}$ pedig a felhasznált tőke-, illetve munkamennyiséget jelöli. A változók felülvonása azok valamilyen statisztikai szürővel (jellemzően HP-szürővel) számított trendértékét jelöli. Ahogy azt 
a (3) egyenlet alapján is láthatjuk, a termelési függvényen alapuló becslések általában a tőke mindenkori optimális (egyensúlyi) felhasználását feltételezik. Ehhez képest a munkainput kihasználtságának értékelésekor a munkanélküliség természetes rátáját (NonAccelerating Inflation Rate of Unemployment - NAIRU) veszik alapul.

Azt látjuk tehát, hogy az iménti módszer a trendszámításnál említett két hiányosságból csak az egyiket képes érdemben kiküszöbölni. Miután a potenciális kibocsátás meghatározása termelési függvényen alapul, így ezúttal nincs szükség a trend- és a ciklikus komponens megkülönböztetését segítő statisztikai feltevések alkalmazására. A (3) egyenlet alapján ugyanakkor azt látjuk, hogy a becslés elvégzése további nem megfigyelt komponensek $\left(\bar{A}_{t}, \bar{L}_{t}, N A I R U\right)$ ismeretét feltételezi. Tekintve, hogy e mennyiségek becslésekor legtöbbször ugyancsak a HP-simítás eredményére támaszkodunk, így végül a kibocsátási rés becslésének az információs halmaz megválasztására mutatott érzékenysége hasonló problémát jelent, mint az előző eljárás esetében (D’Auria és szerzőtársai [2010], Endrész és szerzőtársai [2012], Giorno és szerzőtársai [1995], Mellár [2011]).

Endrész és szerzőtársai [2012] termelési függvény segítségével vizsgálta a termelési tényezők növekedési hozzájárulását és a potenciális kibocsátás alakulását Magyarországon az 1995-től 2012-ig terjedő időszakban. Számításaik szerint a pénzügyi válság kitöréséig a növekedés fö forrása a tőkefelhalmozás és a termelékenység javulása volt, a munka csekély mértékben járult hozzá a potenciális kibocsátás növekedéséhez. A vizsgált időszakban a tőkeállomány megduplázódott, viszont a termelésben felhasznált munkaórák száma stagnált. A pénzügyi válság kitörése után a beruházások tartós visszaesésének folyományaként a tőkebővülés rendkívül lelassult, illetve a termelékenység is visszaesett.

Miután a becslés menetét már áttekintettük, a továbbiakban megvizsgáljuk, hogy miként értelmezhető makrogazdasági szempontból az az egyensúly, amelyet az így becsült potenciális pálya meghatároz. Azt mondhatjuk, hogy a termelési függvényen alapuló becslés két fontos makroökonómiai hipotézisre épít, ezek időrendi sorrendben: a Phillips-görbe és az Okun-törvény (Okun [1962], Phillips [1958]).

A Phillips-görbe megjelenésével világossá vált, hogy a bérek változása szoros kapcsolatban van a munkapiaci helyzettel, így a munkanélküliség alakulásával. Ha az aktuális munkanélküliség magas, meghaladja a természetes ráta szintjét, akkor ez kínálati többletet jelent a munkapiacon, ami a bérek csökkenését (vagy lassabb növekedését) vonja maga után. És fordítva, amikor a munkanélküliség a természetes rátája alá csökken, akkor az feszített munkapiacot eredményez, ahol a munkaerőhiány felfelé nyomja a béreket. Tekintve, hogy a bérek változása jelentős mértékben befolyásolja az aggregált árszínvonal alakulását is, így az átlagbér százalékos változása helyett egyre inkább az inflációt szerepeltették eredményváltozóként a regresszióban. Így aztán közvetlen empirikus kapcsolatot lehetett találni a munkanélküliség és az infláció között.

Az Okun-törvény megjelenésével annyiban módosult ez az átváltás (trade-off), hogy magyarázó változóként a kibocsátási rés jelent meg az összefüggésben (Okun [1962]). Ezek szerint, amennyiben a munkanélküliség aktuális (tényleges) értéke nagyobb (kisebb), mint a természetes ráta által jelölt szint, akkor a kibocsátási rés 
pozitív (negatív), ami felfelé (lefelé) irányuló keresletoldali inflációs nyomást okoz. Ez tehát az úgynevezett NAIRU-megközelítés lényege, ami a potenciális kibocsátást a munkanélküliség egyensúlyi szintjéhez köti (Lucas [1973]).

A fentiek alapján egy termelési függvényben becsült potenciális pálya egydimenziós, másképpen parciális egyensúlyi szemléletet tükröz. A NAIRU-megközelítés alapján ugyanis a munkapiaci egyensúly a potenciális kibocsátási szint elérésének szükséges és elégséges feltétele. Továbbá, az előzőkből következően, az infláció mint a gazdasági túlfütöttség egyetlen és kizárólagos indikátora jelenik meg a vizsgált modellkeretben. A termelési függvényen alapuló eljárás logikáját követve, azt feltételezzük, hogy az infláció értéke minden releváns információt tükröz a gazdaság ciklikus állapotáról. Napjaink gazdasági működését tekintve, a vizsgált modellkeret ezen feltevései problematikusak, a parciális (egydimenziós) egyensúlyi értelmezés meghaladása valós igényként merül fel. A következőkben az egydimenziós egyensúlyi értelmezés meghaladását lehetővé tevő állapottér-modellkeretben vizsgáljuk a kibocsátási rés becslését.

\section{Trend-rés-felbontás exogén magyarázó változókkal}

A kibocsátási rés termelési függvényen alapuló becslése végső soron azt mutatja, hogy az infláció stabilizálása egyúttal a kibocsátási rés stabilizálásához vezet. Ez a következtetés ugyanakkor csak az előbb látott modell keretei között érvényes, ami nem veszi figyelembe a makrogazdasági egyensúly komplex, többváltozós jellegét. ${ }^{5}$ Márpedig a 2008. évi válság egyik legfontosabb tanulsága, hogy a makrogazdasági egyensúly előbb látott parciális értelmezése súlyos problémákkal küzd. Borio és szerzőtársai [2017] szerint az alacsony és stabil infláció önmagában nem garantálja a kibocsátási pálya fenntarthatóságát. A szerzők a pénzügyi ciklus szerepét hangsúlyozva érvelnek a Phillips-görbe-összefüggés sérülése, illetve gyengülése mellett. Egyrészt Drehmann és szerzötársai [2012] eredményeire hivatkozva kifejtik, hogy a pozitív kínálati sokkok gyakrabban jelentkeznek a pénzügyi ciklus felszálló ágán. Másrészt Borio-Lowe [2002] alapján azt is bemutatják, hogy a pénzügyi boom időszakában jellemzően a hazai valuta (reál)felértékelődése figyelhető meg. Belátható, hogy mindkét hatás lefelé nyomja az árakat, így a Phillips-görbe hipotézise ellen hat. Fontos megjegyezni, hogy az elméleti irodalom már jóval a 2008. évi válság elött felismerte a pénzügyi akcelerátor mechanizmusát, de jelentőségét vélhetően alulbecsülte (Bernanke és szerzőtársai [1999], Világi [2012]).

Az adatokat tekintve azt látjuk, hogy 2008 előtt az Egyesült Államokban nem volt különösebb inflációs nyomás: a fogyasztói árak alapján számított éves infláció legmagasabb értéke 3,84 százalék volt. ${ }^{6}$ Erre mondhatnánk, hogy ez közel duplája a Fed

\footnotetext{
${ }^{5}$ Valójában az újkeynesi makromodell és az azzal konzisztens NAIRU-megközelítés jut erre a következtetésre. Ugyanakkor, ahogy azt az előzőkben láttuk, a termelési függvényen alapuló becslés a NAIRU-megközelítésre épít.

${ }^{6}$ Forrás: https://fred.stlouisfed.org/series/FPCPITOTLZGUSA\#0 (Inflation, consumer prices for the United States. FRED, Federal Reserve Bank of St. Louis).
} 
által meghirdetett középtávú célnak, viszont egy alig 4 százalékos inflációs mutató ismeretében vélhetően csak kevesen következtetnének a gazdasági müködés súlyos egyensúlytalanságaira. Csakhogy 2008 előtt olyan nagymértékü, az Egyesült Államok pénzügyi piacairól kiinduló feszültségek alakultak ki, amelyek végül világméretü recesszióhoz vezettek. Borio és szerzőtársai [2017] tanulmánya világosan rámutat arra, hogy az infláció értéke a Phillips-görbe sérülése következtében önmagában ma már nem sokat mond a makrogazdasági egyensúly állapotáról. Következésképpen a reál-GDP trend-rés-felbontásakor érdemes a különböző pénzügyi változók (eladósodottság, hitel-tőke-arány, tőkeáttétel) értékét is figyelembe venni.

Ebből a szempontból különösen is érdekes a Darvas-Simon [2002] tanulmány, amelyben a szerzők a financiálisan fenntartható kibocsátás definiálásával már jóval korábban túllépnek a makroegyensúly egydimenziós, parciális értelmezésén. A szerzők lényegi észrevétele, hogy kis, nyitott gazdaságok esetében a túlkereslet nem feltétlenül növeli az inflációt. A túlkereslet ugyanis többnyire az import növekményében jelenik meg. Mindezek alapján belátható, hogy önmagában az infláció értéke nem jelzi megbízhatóan a gazdaság esetleges túlfütöttségét. A kibocsátási rés megbizhatóbb becslése ezek szerint mindenképpen többdimenziós szemlélet, tehát valamilyen többváltozós modellt igényel. A következőkben amellett érvelünk, hogy az állapottér-modellkeret alkalmas eszköze lehet a makrogazdasági egyensúly többdimenziós, illetve többváltozós jellegét szem előtt tartó trend-rés-felbontások elkészítésének.

Elöljáróban tisztáznunk kell, hogy az alábbi állapottérmodellben csak a hazai reálGDP trend-rés-felbontása történik meg. Így ez lesz a filterezés, vagyis a dekompozíció egyetlen endogén változója. Ennek megfelelően a továbbiakban is egyváltozós filterezésről beszélünk, viszont az alábbiakban vizsgált állapottérmodellt - a specifikációban szereplő exogén magyarázó változók információtartalmát hangsúlyozandó - többváltozósnak tekintjük.

\section{Modellspecifikáció}

Az elsőként vizsgált többváltozós megközelítés alapgondolata, hogy a reál-GDP trend-rés-felbontása során különböző exogén magyarázó változók információtartalmát is figyelembe vesszük. Ebben az értelmezésben a potenciális pálya továbbra is trendértékek idősorát jelenti, de a legegyszerübb idősoros technikák alkalmazásához képest már támaszkodhatunk - mind empirikus, mind elméleti szempontból releváns változók információtartalmára is (Borio és szerzőtársai [2014]). Például az inflációnak vagy a folyó fizetési mérleg GDP-arányos egyenlegének egy hosszú távú célértéktöl (teljes mintabeli átlag) vett eltérése vélhetően a reálkibocsátás ciklikus pozíciójáról is hasznos információval szolgál. Mindez egy állapottérmodellben úgy írható le, hogy a kibocsátási rés állapotegyenletében különböző exogén magyarázó (bemeneti) változókat szerepeltetünk (Borio és szerzőtársai [2014], [2017]). Az „üres” HP-szürő állapottér-reprezentációjához képest (lásd Harvey-Jaeger [1993] 233. o.) a kibocsátási rés állapotegyenletét három exogén változóval $\left(p c_{1}, p c_{2}, p c_{3}\right)$ egészítjük ki az alábbiak szerint: 


$$
\begin{aligned}
100 y_{t} & =\bar{y}_{t}+\hat{Y}_{t} \\
\bar{y}_{t} & =2 \bar{y}_{t-1}-w_{t-1}+\varepsilon_{1, t}, \quad \varepsilon_{1, t} \sim N\left(0, \sigma_{1}\right) \\
w_{t} & =\bar{y}_{t-1} \\
\hat{Y}_{t} & =c_{1} p c_{1}+c_{2} p c_{2}+c_{3} p c_{3}+\varepsilon_{2, t}, \quad \varepsilon_{2, t} \sim N\left(0, \sigma_{2}\right)
\end{aligned}
$$

A HP-szűrő állapottér-reprezentációjához képest egy további módosításra kell még felhívnunk a figyelmet. A (4) megfigyelési egyenlet szerint a reál-GDP logaritmusát százzal szorozzuk, hogy a trend-rés-felbontás eredményeként adódó kibocsátásirésértékeket már eleve százalékos formában kapjuk. ${ }^{7}$ A modell megfigyelési egyenletét érintő módosítás után tekintsük a kibocsátási rés állapotegyenletének specifikációját. A (7) egyenletben három exogén magyarázó változó $\left(p c_{1}, p c_{2}, p c_{3}\right)$ szerepel, egyegy becsülendő paraméter $\left(c_{1}, c_{2}, c_{3}\right)$ mellett. A (7) egyenletben szereplö exogén változók, esetünkben statikus fókomponensek, részletes leírást az alábbi alfejezetekben tárgyaljuk. A specifikációban szereplő exogén változóktól mindenekelőtt azt várjuk, hogy releváns információt hordozzanak a gazdasági konjunktúra állapotáról. Ezzel a modellezési stratégiával találkozhatunk a Borio és szerzőtársai [2017] tanulmányban, ahol a szerzők kimondottan a pénzügyi változók modellbe foglalását vizsgálják. Hipotézisük szerint a pénzügyi ciklus pozíciója fontos többletinformációt hordoz a reálgazdasági ciklus állapotáról. A szerzők meggyőzően igazolják hipotézisüket: a pénzügyi ciklus információtartalmának felhasználásával robusztusabb és a 2008. évi válságot tekintve jóval valószerübb kibocsátásirés-becslésekhez jutnak (Borio és szerzötársai [2017]).

Mi ehhez képest az exogén változók kiválasztásakor csak azt tartottuk szem elött, hogy lehetőség szerint minél több releváns információval járuljanak hozzá a dekompozícióhoz. Az alábbiakban különböző survey-adatok felhasználásával végezzük el a reál-GDP trend-rés-felbontását.

\section{Felhasznált adatok}

A reálgazdaság ciklikus pozíciójának megítélésében sokat segíthet, ha a hivatalos statisztikák (az úgynevezett kemény adatok) mellett - esetleg azok helyett - különböző felmérések eredményeire, survey-adatokra támaszkodunk. Ez a megközelítés a hazai szakirodalomban először Rácz [2012] tanulmányában jelent meg, aki AastveitTrovik [2014] és Nyman [2010] korábbi eredményeit szintetizálta. Munkájában a Gazdaságkutató Intézet ESI felmérésének adataira támaszkodva igyekszik felmérni a GDP ciklikus komponensét.

A Rácz [2012] tanulmányban hivatkozott ESI-adatok az Eurostat honlapján nyilvánosan is elérhetők (European Stability Initiative, ESI), az Európai Unió fontosabb gazdasági indikátorait (Principal European Economic Indicators, PEEIs) tartalmazó

\footnotetext{
${ }^{7}$ Ezt az eredmények könnyebb interpretációját segítő korrekciót a következő fejezetben vizsgált állapottérmodellben is alkalmazni fogjuk.
} 
Euroind-adatbázisban. ${ }^{8}$ A felmérés az Európai Bizottság Gazdasági és Pénzügyi Főigazgatóságának (European Commission's Directorate General for Economic and Financial Affairs) megbízásából készült el, és a fogyasztók, valamint a vállalatok jövőre vonatkozó kilátásait, optimizmusát próbálja számszerüsíteni. Az adatok -100 és +100 közötti skálán mozognak, tehát szintjük nem sok információt hordoz. Ennek ellenére mégis értékesek és hasznosak, hiszen az adatok dinamikájából sok mindenre következtethetünk. A várakozások, a bizalom, valamint a vállalkozói optimizmus vagy a bizonytalanság ugyanis jelentősen befolyásolhatja a makrogazdasági változók alakulását. ${ }^{9}$ A reál-GDP esetében ezúttal is a KSH negyedéves idősorát használtuk a becsléshez.

A modellt a 2000 első negyedévétől 2016 negyedik negyedévéig terjedő, ezáltal 69 érvényes megfigyelést tartalmazó mintán becsültük meg.

\section{Becslési módszer}

A fenti specifikáció becsléséhez először a ciklikus indikátorokban rejlő közös információ kinyerésére volt szükség. Ennek egy alkalmas eszköze lehet a statikus fökomponens-analízis, ami azzal a feltételezéssel él, hogy az indikátorok időbeli szóródásának, változásának egy vagy több közös meghatározó faktora van (Hajdu [2003]). A főkomponens-elemzés elvégzése előtt egy egyszerű frekvenciakonverziót hajtottunk végre: a 47 havi frekvenciájú idősor esetében számtani átlagolással képeztünk negyedéves adatokat. Így összességében 65 negyedéves bontású ciklikus indikátor alapján végeztük el a főkomponens-elemzést.

A statikus főkomponens-elemzés módszere lényegében egy súlyvektort határoz meg, amellyel súlyozva a változókészlet minden elemét, az adott (első) főkomponens egyetlen idősorként áll elő. Az első statikus főkomponenshez tartó súlyvektor (sajátvektor) ráadásul úgy határozódik meg, hogy az adatok közös varianciájának legnagyobb részét fedje le. Amennyiben elfogadjuk, hogy a változókészletben lévő információt a változók összes varianciájával mérjük, akkor azt is mondhatjuk, hogy az első főkomponens kiemelésével az információveszteség minimális lesz (Hajdu [2003]). A futtatások eredményei alapján végül három statikus fökomponens kiválasztása mellett döntöttünk.

A HP-szürő állapottér-reprezentációját tekintve belátható, hogy a $\lambda=1600$ paraméterü HP-simítás eredménye reprodukálható egy megfelelően kalibrált Kálmánszürőben. A fenti (7) egyenlet alapján ugyanakkor azt látjuk, hogy a ciklikus komponens $(\hat{Y})$ varianciáját nemcsak a vonatkozó véletlen tag szórása $\left(\sigma_{2}\right)$ befolyásolja, hanem a jobb oldalon szereplő exogén változók addicionális varianciája és azok becsült együtthatói is. Amennyiben tehát szeretnénk fenntartani a trend gyorsulásának, valamint a ciklikus komponensnek a HP-simítás eredményét tükröző relatív

${ }^{8} \mathrm{http}: / / \mathrm{ec}$. europa.eu/eurostat/web/euro-indicators/data/euro-indicators-database (Business and consumer surveys $\rightarrow$ Business surveys $\rightarrow$ NACE Rev. 2 activity).

${ }^{9}$ Érdeklődés esetén szívesen rendelkezésre bocsátjuk az adatbázisban szereplő negyedéves és havi frekvenciájú idősorok leírását tartalmazó táblázatokat. 
volatilitását, akkor a $\operatorname{var}(\hat{Y}) / \operatorname{var}\left(\Delta^{2} \bar{Y}\right)=1600$ megkötést kell alkalmaznunk, ahol $\Delta^{2} \bar{Y}$ a potenciális kibocsátás második differenciáját jelöli (Harvey-Jaeger [1993], Hodrick-Prescott [1997]).

A restrikciótól lényegében azt várjuk, hogy az exogén változók információtartalma a hazai reálgazdasági ciklus feltételezett frekvenciája mellett jelenjen meg a becslési eredményekben (Borio és szerzötársai [2017]). Belátható, hogy a fenti modellben a kívánt restrikció teljesüléséhez a $\sigma_{2} / \sigma_{1}$ arány megfelelő kalibrálása szükséges, amit egy kereső algoritmus segítségével végeztünk el. ${ }^{10}$ Mindezt a modellspecifikációban a következők szerint jelenítjük meg:

$$
\begin{aligned}
100 y_{t} & =\bar{y}_{t}+\hat{Y}_{t} \\
\bar{y}_{t} & =2 \bar{y}_{t-1}-w_{t-1}+\varepsilon_{1, t}, \quad \varepsilon_{1, t} \sim N\left(0, \sigma_{1}\right) \\
w_{t} & =\bar{y}_{t-1} \\
\hat{Y}_{t} & =c_{1} p c_{1}+c_{2} p c_{2}+c_{3} p c_{3}+\varepsilon_{2, t}, \quad \varepsilon_{2, t} \sim N\left(0, \kappa \sigma_{1}\right)
\end{aligned}
$$

A kereső algoritmus $\kappa$ értékét egy külső ciklusban változtatva fut egészen addig, míg a modell paramétereinek maximum likelihood becslése (a belső ciklusban) nem eredményezi a $\operatorname{var}(\hat{Y}) / \operatorname{var}\left(\Delta^{2} \bar{Y}\right)=1600$ egyenlőség kellően pontos teljesülését. Adott $\kappa$-érték mellett a fenti modell paramétereinek maximum likelihood becslése az alábbi loglikelihood függvény maximalizálásával történik (Harvey [1990] 126. o.): ${ }^{11}$

$$
\max _{\left\{c_{1}, c_{2}, c_{3}, \sigma_{1}\right\}} L L\left(c_{1}, c_{2}, c_{3}, \sigma_{1}\right)=-\frac{T}{2} \log (2 \pi)-\frac{1}{2} \sum_{t=1}^{T} \log \left(S_{t}\right)-\frac{1}{2} \sum_{t=1}^{T} \frac{z_{t}^{2}}{S_{t}} .
$$

\section{A modellbecslés eredménye}

A maximum likelihood becslés eredményét az 1. táblázatban láthatjuk. A paraméterek pontbecslése mellett azok standard hibáját, $z$-statisztikáját és $p$-értékét tüntettük fel.

\section{1. táblázat}

Exogén változók bevonásával végzett modellbecslés eredménye

\begin{tabular}{lcccc}
\hline & Koefficiens & Standard hiba & $z$ & $p$ \\
\hline$c_{1}$ & 0,308 & 0,066 & 4,642 & 0,000 \\
$c_{2}$ & 0,247 & 0,181 & 1,363 & 0,172 \\
$c_{3}$ & 0,310 & 0,171 & 1,813 & 0,069 \\
$\sigma_{1}$ & 0,013 & 0,114 & $-37,703$ & 0,000 \\
\hline
\end{tabular}

Forrás: saját szerkesztés.

\footnotetext{
${ }^{10}$ A kereső algoritmus implementálásában Várpalotai Viktor volt segítségünkre.

${ }^{11}$ A számításokat a Matlab saját beépített Econometrics Toolboxának függvényeivel végeztük el.
} 
Az 1. táblázat első három sora a kibocsátási rés állapotegyenletében szereplő főkomponensek becsült együtthatóit mutatja. Ez alapján azt látjuk, hogy az első főkomponenshez tartozó együttható minden szinten szignifikáns, a harmadik főkomponens koefficiense ugyanakkor csak 10 százalékos szinten. A második fökomponenst végül azért hagytuk a modellben, mert annak hiányában az első főkomponens már egyértelmüen kiszorította volna a harmadikat is.

Ezzel együtt is úgy gondoljuk, hogy egy 69 megfigyelést tartalmazó mintán futó Kálmán-szűrő esetében a maximum likelihood becslés 1 . táblázatban látható eredménye viszonylag stabilnak mondható. Az állapottérmodellek paramétereinek klaszszikus likelihood-elven alapuló becslésével lényegében csak a téma szintetizáló irodalmában találkozhatunk (Durbin-Koopman [2012], Harvey [1990], Kuttner [1994]). Az általunk is hivatkozott empirikus tanulmányokban szinte mindenütt a paraméterek Bayes-becslését látjuk (Benes és szerzőtársai [2010], Blagrave és szerzőtársai [2015], Borio és szerzőtársai [2017], Tóth [2011]). Jóllehet a következőkben vizsgált többváltozós trend-rés-felbontás esetében mi is rákényszerültünk a modell paramétereinek bayesi becslésére, ezúttal a paraméterek maximum likelihood becslését, a bemutatott kompromisszumokkal együtt is, megalapozottabb eljárásnak találtuk.

Ezek után a modellben becsült kibocsátási rés, valamint az az alapján számított potenciális növekedési pálya idősorait vizsgáljuk. A 3. ábra a kibocsátási rés mint állapotváltozó simított idősorát mutatja.

\section{3. ábra}

A kibocsátási rés exogén változók bevonásával végzett becslése, 2002. I. negyedév-2016. IV. negyedév

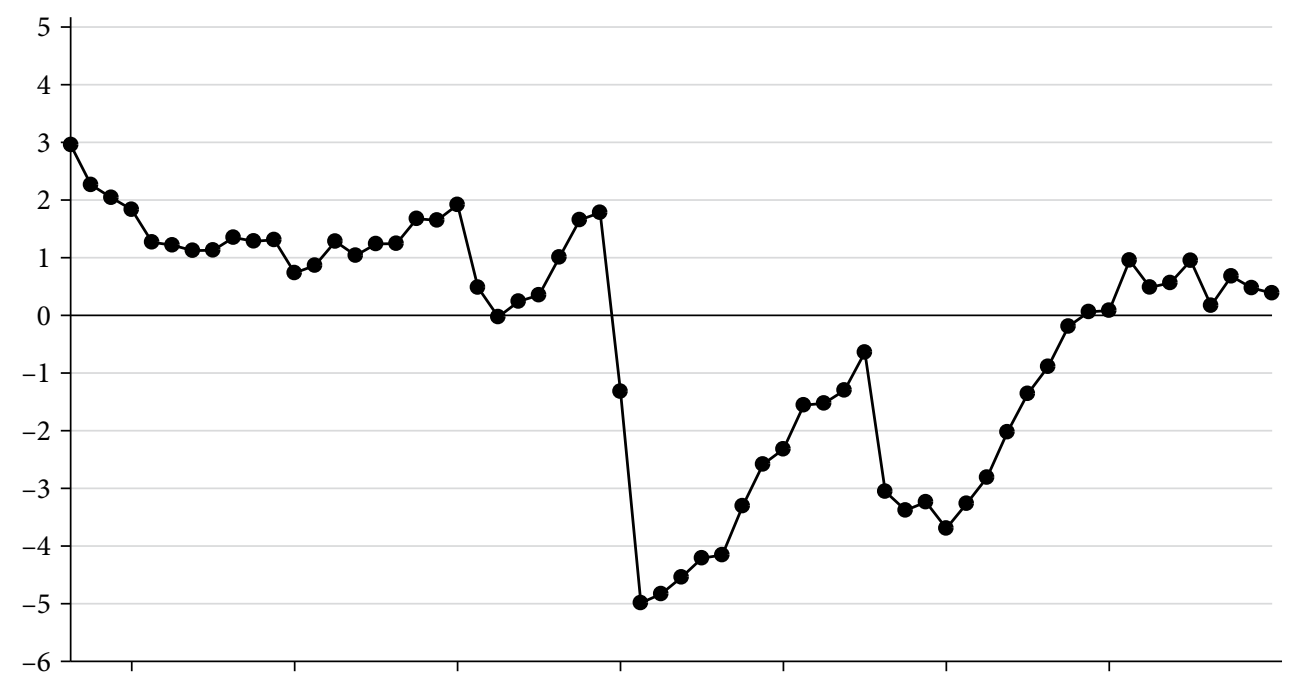

2002. IV. né. 2004. IV. né. 2006. IV. né. 2008. IV. né. 2010. IV. né. 2012. IV. né. 2014. IV. né.

Forrás: saját szerkesztés.

Előzetesen azt várjuk, hogy a statikus főkomponensek bevonásával végzett filterezés megalapozottabb, intuitívebb eredményeket produkáljon, mint az „üres” HP-szürő. 
A 3. ábrán látható eredmények azonban - a szofisztikáltabb eljárás ellenére is - némi kételyt ébresztenek. Mindenekelőtt megkérdőjelezhető az a becslési eredmény, hogy a kibocsátási rés már 2002 elején 3 százalék volt, és éppen a fiskális alkoholizmus ezt követő éveiben mérséklődött. Ahogy azt már megállapítottuk, a gazdaságpolitikai intézkedések és a makrogazdasági adatok sokkal inkább ennek a dinamikának, illetve tendenciának az ellenkezőjét valószínüsítik: a kezdeti kismértékủ, majd később egyre nagyobb kibocsátási rés kialakulását, egyúttal a potenciális növekedés lassulását. Úgy gondoljuk, a 2006. végi visszafogás következménye ugyancsak túlzottá válik ebben a modellbecslésben. Valószínüsíthető, hogy a megszorító csomagok hatására 2007ben csökkent a pozitív kibocsátási rés, de nehezen képzelhető el, hogy egy korábbról hozott, vélhetően nagymértékü, pozitív rés teljes egészében záródna.

A válságot megelőző időszak megkérdőjelezhető eredményei azzal magyarázhatók, hogy a modellbe bevont fökomponensek csak és kizárólag survey-adatok információtartalmát tömörítik. Ehhez képest az olyan kemény statisztikák, mint az egyensúlyi mérlegmutatók (a folyó fizetési mérleg egyenlege, költségvetési deficit) sokat mondhatnának a fiskális alkoholizmus éveit jellemző egyensúlytalanságokról. Így tehát arra a következtetésre jutunk, hogy egy survey-adatokat és kemény statisztikákat egyaránt felhasználó főkomponens-elemzés közelebb vihetne bennünket a valósnak vélt dinamika feltárásához. ${ }^{12}$

A 2008. évi válságot követő időszakra ezzel együtt is valószerübbnek látszó, intuitív eredményeket kapunk. A becslési eljárás javára írható, hogy a gazdasági fellendülés 20112012. évi megtorpanását, valamint a negatív kibocsátási rés időszak végi záródását és pozitívba való átmenetét véleményünk szerint helyesen tükrözi vissza. Tekintve ugyanakkor, hogy a modell specifikációja során a HP-szürő állapottér-reprezentációjából indultunk ki, a végponti értékelés szempontjából ezúttal is óvatosnak kell maradnunk.

Ezúttal is elmondható: egy kibocsátásirés-becslés értékelésekor kulcsfontosságú, hogy az adott becslés milyen potenciális pályát, illetve milyen ütemű (éves) potenciális növekedést implikál a vizsgált időszakra. A 4. ábra a fenti modell eredményei alapján kalkulált potenciális növekedési pályát mutatja.

A 4. ábrán a folytonos vonal jelöli a reál-GDP éves százalékos növekedési ütemét, míg a szaggatott vonal a HP-szürt becslésböl adódó potenciális növekedési ütemek idősora. Ehhez képest a körökkel megrajzolt vonal az exogén változók bevonásával végzett modell becslése alapján kalkulált éves potenciális növekedési ütemek idősorát mutatja. A 4. ábrán azt látjuk, hogy modellünk az „üres” HP-szüröhöz viszonylag hasonló potenciális növekedési pályát jelez a vizsgált időszakra. A válságot megelőző időszakban a HP-szűrő alapján kalkulált potenciális növekedési pályához képest valamivel nagyobb növekedési rátákat tapasztalunk. Ehhez képest a fenti modell alapján a válság utáni időszakra némileg alacsonyabb potenciális növekedési ráták adódnak. A potenciális növekedés ütemének válságot követő jelentős visszaesése tehát a 2. ábrán látottakhoz hasonlóan ezúttal is megfigyelhető.

\footnotetext{
${ }^{12}$ Egy ilyen vizsgálat további kutatás tárgyát képezheti. Jelen tanulmány azonban elsősorban a lehetséges modellezési, modellépítési stratégiák bemutatására törekszik. Ezzel együtt a 2008. évi válságot követő időszakra megalapozottnak látszó (a következőkben tárgyalt modellekkel jól összevethető) eredményeket kapunk.
} 


\section{4. ábra}

Tényleges és exogén változók bevonásával végzett modellbecslés eredménye alapján számított éves potenciális növekedés, 2003. I. negyedév-2016. IV. negyedév

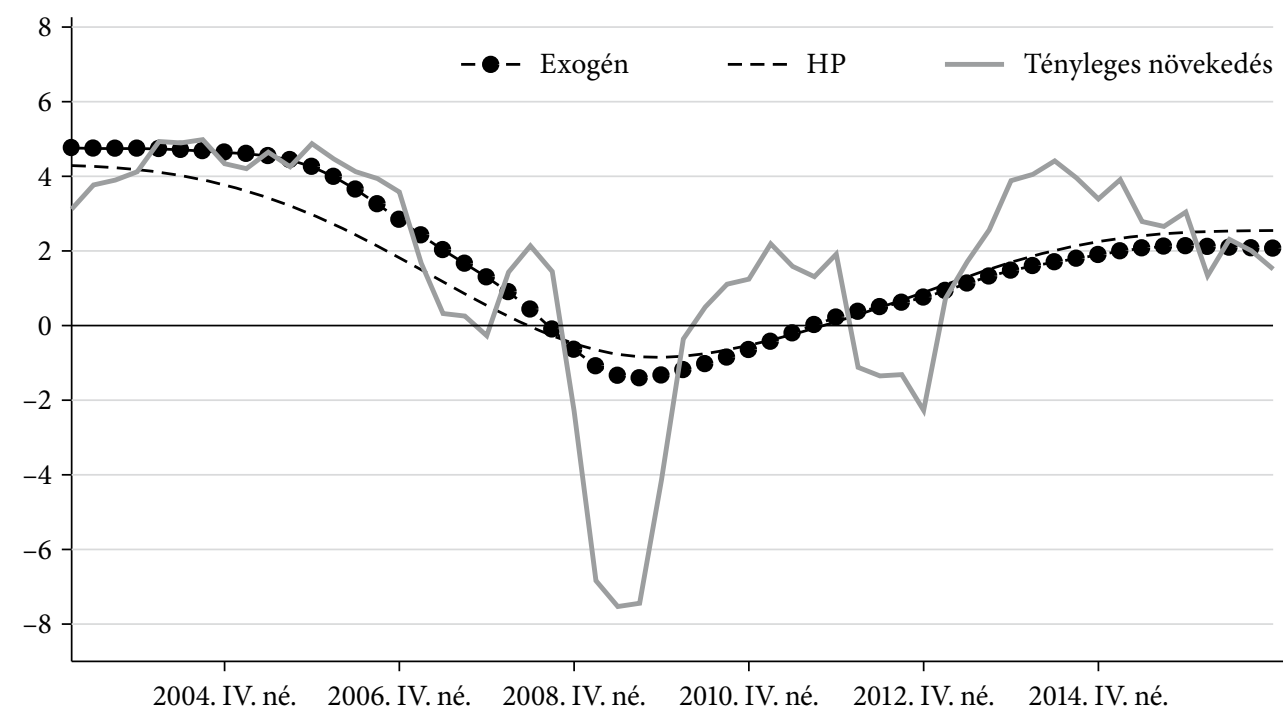

Forrás: saját szerkesztés.

\section{Többváltozós kvázistrukturális modell}

Az előbb látott modellben csak a reálkibocsátás $\left(Y_{t}\right)$ trend-rés-felbontása történt meg, ez volt tehát modell egyetlen endogén változója. A kibocsátási rés állapotegyenletében szereplő exogén magyarázó változók (fökomponensek) információtartalmát hangsúlyozandó, a fenti modellt is többváltozósnak tekintettük. Ehhez képest a következőkben egy olyan modellt mutatunk be, amelyben már több endogén változó trend-rés-felbontása is megjelenik. Ez a megközelítés az előzőhöz képest jóval nagyobb méretű modellt és bonyolultabb, egyúttal érzékenyebb specifikációt eredményez (Borio és szerzőtársai [2014]).

Az alábbiakban tárgyalt modellt kvázistrukturálisnak nevezzük, mivel a makroökonómiai elmélet bizonyos releváns összefüggései (Phillips-görbe, Okun-törvény) megjelennek a többváltozós statisztikai szürő specifikációjában.

\section{Modellspecifikáció}

A modellspecifikáció Benes és szerzötársai [2010], Konuki [2010], Tóth [2011], valamint Blagrave és szerzőtársai [2015] munkáin alapulnak. Bizonyos blokkok kialakításakor viszont azoktól jelentősen eltérő, egyedi megoldásokat követtünk.

Már említettük, hogy egy több endogén változót tartalmazó modell felépítése és becslése jóval bonyolultabb az előzőkben látottakhoz képest. Mi indokolhatja ennek 
ellenére egy ilyen típusú modell alkalmazását? E kérdés megválaszolásához tekintsük az előző fejezetben látott modell megfigyelési egyenletét, amely tehát a potenciális kibocsátásra, illetve annak logaritmusára és a kibocsátási résre fogalmazott meg egy triviális összefüggést: a mérési hibáktól eltekintve, az említett mennyiségek összegének a reálkibocsátás logaritmusát kell eredményeznie: $100 y_{t}=\bar{y}_{t}+\hat{Y}_{t}$. Ennek alapján belátható, hogy ha modellünk több változó trend-rés-felbontását is tartalmazza, akkor a megfigyelési egyenletként felhasználható plauzibilis összefüggések száma is bővül. Az alábbiakban egy olyan modellt vizsgálunk, melyben a reálkibocsátás mellett az infláció, a munkanélküliség és a kereskedelmi mérleg egyenlegének trend-résfelbontása is megjelenik. ${ }^{13}$ Ennek megfelelően többváltozós kvázistrukturális modellünk megfigyelési egyenletei a következők.

$$
\begin{aligned}
100 y_{t} & =\bar{y}_{t}+\hat{Y}_{t} \\
U_{t} & =\bar{U}_{t}+\hat{U}_{t} \\
\pi_{t} & =\bar{\pi}_{t}+\hat{\pi}_{t} \\
\pi_{t}^{T} & =\bar{\pi}_{t}+\epsilon_{t}^{T}, \quad \epsilon_{t}^{T} \sim N\left(0, \sigma_{\epsilon}\right) \\
X_{t} & =\bar{X}_{t}+\hat{X}_{t}
\end{aligned}
$$

A (13)-(17) megfigyelési egyenletek - eltekintve a (16) egyenlettöl- triviális összefüggéseket írnak le. Ezek szerint azt várjuk, hogy az egyes változók trendjének és cikluskomponensének összege a változók tényleges értékét eredményezze. Ehhez képest a (16) megfigyelési egyenlet szerepe már jóval érdekesebb. Tóth [2011] megoldásához hasonlóan ezzel az egyenlettel az infláció trendjét szerettük volna bizonyos mértékben rögzíteni a jegybank aktuális középtávú inflációs céljának megfelelöen. Ez esetben $\epsilon_{t}^{T}$ hibatag varianciájának megfelelö kalibrálása különösen is fontos.

A megfigyelési egyenletek után tekintsük most modellünk állapotegyenleteit, amelyekben tehát a makroökonómiai elmélet néhány alapvetö összefüggésére támaszkodunk (Mellár [2008]). A gazdaság makroszintü müködése szempontjából releváns összefüggések (Phillips-görbe, Okun-törvény) segítenek minket abban, hogy elméleti és empirikus szempontból is megalapozott kapcsolatot teremtsünk az egyes változók ciklikus és trendkomponensei között. Mindenekelött lássuk a potenciális kibocsátás állapotegyenletét!

A potenciális kibocsátásról azt feltételezzük, hogy pályája egy véletlen bolyongáshoz hasonló folyamatot követ. A klasszikus véletlenbolyongás-folyamathoz képest ugyanakkor az egyenletben megjelennek a munkanélküliség trendjében bekövetkezett változások. Azt feltételezzük ugyanis, hogy a kibocsátás trendjét közvetlenül érintik a munkanélküliség trendjében bekövetezett változások. Cobb-Douglas-típusú termelési függvényt feltételezve, a (18) egyenletben szereplő $\alpha_{11}$ paraméternek fontos strukturális jelentése is van, hiszen ebben az esetben a munka parciális termelési

\footnotetext{
${ }^{13}$ Definíció szerint a kereskedelmi mérleg egyenlege az árukivitelt (aktív oldal) és az árubehozatalt (passzív oldal) tartalmazza. Ehhez képest mi az áruk és szolgáltatások együttes egyenlegére gondolunk, amikor a kereskedelmi mérleg fogalmát használjuk.
} 
rugalmasságát jeleníti meg, amely tökéletes verseny mellett a bérjövedelmek arányával egyenlő. Ez az elméleti tudás természetesen a paraméter identifikációját, illetve a prior eloszlás meghatározását is nagyban segíti.

$\bar{y}_{t}=\bar{y}_{t-1}-\alpha_{11}\left(\bar{U}_{t}-\bar{U}_{t-1}\right)+\varepsilon_{t}^{\bar{y}}$.

Tóth [2011] modelljében ehhez képest a strukturális munkanélküliség növekedése egyszerre két úton (időhorizonton) is lassítja a potenciális növekedést: egyrészt rövid távon, másrészt középtávon, és ez utóbbi hatás valamiképpen a tőkeállomány lassabb alkalmazkodását hivatott helyettesíteni. Mi ez utóbbi hatást figyelmen kívül hagytuk a specifikációban, jelentősen növelve ezáltal a becsléshez használható minta terjedelmét. A (18) egyenlet specifikációjában érdemes megfigyelni, hogy a termelési függvényre alapozott eljárás alapgondolata részben megjelenik ebben a modellkeretben is: a munkanélküliség trendjének növekedése ezúttal is csökkenti a potenciális kibocsátást.

Ezek után tekintsük a kibocsátási rés állapotegyenletét! Mindenekelőtt a kibocsátási rés perzisztenciáját egy elsőrendü autoregresszív tag szerepeltetésével igyekszünk biztosítani. Ezen felül, követve az előző modell felépítését, két exogén magyarázó változót is szerepeltetünk a kibocsátási rés állapotegyenletében. Úgy gondoljuk, hogy az ipari kapacitáskihasználtság szintje (mintabeli átlagtól vett eltérés, $\hat{C}_{t}$ ) fontos információt adhat a gazdasági konjunktúra állapotáról. Ezt az elképzelést erősíti, hogy az MNB inflációs jelentésében a kibocsátási rés becslése mellett feltünteti az ipari kapacitáskihasználtság alakulását is (MNB [2017]). Továbbá, mivel Magyarország egy kis, nyitott gazdaság, joggal feltételezhetjük, hogy a hazai gazdaság ciklikus pozíciója valamilyen mértékben együtt mozog az EU15-öt jellemző konjunktúrával. Az Európai Bizottság Gazdasági és Pénzügyi Főigazgatóságának az EU15-re vonatkozó kibocsátásirés-becslését $\left(Y_{t}^{E U}\right)$ felhasználva képet kaphatunk a nemzetközi konjunktúra állapotáról. Mindezt a Tóth [2011] tanulmányában látottakhoz képest jóval tömörebb specifikációval érjük el, ahol a szerző egy teljes külföldi blokk építésével, a modellbecslés eredményeként jut el egy hasonló tartalmú változóhoz. Ezek után a kibocsátási rés állapotegyenlete a következő:

$\hat{Y}_{t}=\beta_{11} Y_{t-1}+\beta_{12} \hat{C}_{t}+\beta_{13} \hat{C}_{t}^{E U}+\varepsilon_{t}^{\hat{Y}}$.

Ezt követően a filterezés második endogén változójának, a munkanélküliségnek a trendrés-felbontásával kapcsolatos modellezési megfontolásokat vizsgáljuk. A munkanélküliség trendkomponensét a jelen modellkeretben a munkanélküliség egyensúlyi vagy természetes rátájaként értelmezzük. Benes és szerzötársai [2010] azt feltételezi, hogy a természetes munkanélküliségi ráta alakulását két - különböző mértékben perzisztens - sokk is befolyásolja. Modelljükben a kibocsátási rés is szerepel a munkanélküliség trendkomponensének állapotegyenletében. Ezáltal a szerzők az úgynevezett hiszterézis jelenségére reflektálnak: egy rövid távú, átmeneti sokk permanens hatást gyakorolhat a gazdaság mint dinamikus rendszer hosszú távú működésére (Váry [2018]). Másrészt a modellben a kibocsátás ciklikus komponensét érintő változások (például keresleti sokkok) a munkanélküliség trendkomponensén keresztül fejtik ki hatásukat a kibocsátás trendjére. A munkanélküliség trendjének növekedése ugyanis itt is a reálkibocsátás trendjének 
csökkenését okozza. Ezek szerint a kibocsátás ciklikus komponensében megjelenő átmeneti, keresletoldali ingadozások - például recesszióban a kibocsátás nagymértékü viszszaesése - nem csak átmeneti hatásokkal járnak.

A hiszterézis jelenség intuitív értelmezése alapján azt mondhatjuk, hogy a recesszió évei során olyan nehezen visszafordítható negatív folyamatok indulhatnak el, mint a termelőkapacitások leépítése és a strukturális munkanélküliség növekedése. Ezek aztán a későbbiekre nézve tartósan korlátozhatják a gazdaság potenciális növekedését (Ball [2009], Blanchard-Summers [1986]).

Mi ehhez képest Tóth [2011] megoldását követve és a becsülendő paraméterek számát korlátozva, egy jóval egyszerübb, véletlen bolyongást követő folyamatot feltételezünk a munkanélküliség trendkomponensére. Ez ugyanakkor nem zárja ki annak a lehetőségét, hogy a becslési eredményeket látva a hiszterézis megnyilvánulására következtessünk (lásd később a 8. ábrát). Az egyszerübb specifikáció választásával csupán az esetleges hiszteretikus hatások számszerüsítéséről mondunk le. Ezek után a munkanélküliség trendkomponensének alakulást az alábbi egyenlettel írjuk le:

$\bar{U}_{t}=\bar{U}_{t-1}+\varepsilon_{t}^{\bar{U}}$.

A munkanélküliség ciklikus komponensét az Okun-törvény felhasználásával modellezzük. Az Okun-törvény eredetileg a munkanélküliségi ráta aktuális értéke és a kibocsátási rés között fogalmazott meg egy egyszerü, empirikusan releváns összefüggést (Okun [1962]). Erre a hipotézisre építve kötjük össze a kibocsátás és a munkanélküliség ciklikus komponensének alakulását:

$\hat{U}_{t}=\beta_{21} \hat{U}_{t-1}-\beta_{22} \hat{Y}_{t}+\varepsilon_{t}^{\hat{U}}$.

Az infláció esetében is véletlen bolyongást feltételezünk a trendkomponens alakulására. Ezek szerint a hosszú távú inflációs várakozások alakulását az alábbi folyamat írja le:

$\bar{\pi}_{t}=\bar{\pi}_{t-1}+\varepsilon_{t}^{\bar{\pi}_{t}}$.

Az infláció ciklikus komponensének modellezésekor egy egyszerü Phillips-görbeösszefüggésre építünk, így a ciklikus komponensre a következő állapotegyenletet íruk fel (Phillips [1958]):

$\hat{\pi}_{t}=\beta_{31} \hat{\pi}_{t-1}+\beta_{32} \hat{Y}_{t-1}+\varepsilon_{t}^{\hat{\pi}}$.

Modellünk utolsó endogén változója az áruk és szolgáltatások GDP-arányos közös egyenlege, amit a továbbiakban, némi egyszerüsítéssel élve, kereskedelmi mérlegként említünk. Ezáltal - a folyó fizetési mérleg használatához képest - kiszürjük a jövedelmek egyenlegének és a viszonzatlan folyó átutalásoknak az esetleges torzító hatását. Különösen a viszonzatlan folyó átutalások tartalmaznak olyan tételeket, amelyek függetlenek a hazai konjunktúra állapotától. ${ }^{14} \mathrm{~A}$ kereskedelmi mér-

\footnotetext{
${ }^{14}$ Az Európai Unió közös költségvetésébe történő befizetések a viszonzatlan folyó átutalások egyenlegében jelennek meg. Ehhez képest a strukturális alapokból történő kifizetések a tőkemérlegben kerülnek könyvelésre. Ezek alapján akár a GDP-arányos felülről számított finanszírozási képesség is valósabb képet mutat a hazai konjunktúra állapotáról, mint önmagában a folyó fizetési mérleg egyenlege.
} 
leg egyenlegének trendkomponensére, az előzőkhöz hasonlóan, véletlen bolyongást feltételezünk:

$\bar{X}_{t}=\bar{X}_{t-1}+\varepsilon_{t}^{\bar{X}}$.

Végül, a kereskedelmi mérleg ciklikus komponensét a (25) állapotegyenlet írja le: $\hat{X}_{t}=\beta_{41} \hat{X}_{t-1}-\beta_{42} \hat{Y}_{t}+\varepsilon_{t}^{\hat{X}}$.

Azt látjuk, hogy a kereskedelmi mérleg ciklikus komponensére vonatkozó (25) egyenlet a kibocsátási rés azonos időszaki értékét negatív előjellel szerepelteti. Ezáltal próbálunk reflektálni a specifikációban a korábban már hivatkozott Darvas-Simon [2002] tanulmány lényegi észrevételére. Ezek szerint kis, nyitott gazdaságok esetében a gazdaság túlfütöttsége nemcsak inflációs nyomást generál, hanem az importjavak iránti keresletet is növeli, egyúttal rontja (ceteris paribus) a kereskedelmi mérleg egyenlegét.

A fentiek alapján azt mondhatjuk, hogy az állapottér-modellkeret lehetőséget adott arra, hogy a becslés során a termelési függvényen alapuló eljáráshoz képest további, akár elméleti, akár empirikus szempontból releváns összefüggésekre építsünk. A Phillips-görbe és az Okun-törvény implementálásán túl egy a makrogazdasági egyensúly szempontjából ugyancsak meghatározó összefüggésre tudtunk támaszkodni, amely tehát a kibocsátási rés és a kereskedelmi mérleg ciklikus komponensének negatív korrelációjára épít (Frankel [2011], Obstfeld-Rogoff [1996], Tóth [2011]). Pusztán a specifikációt tekintve azt mondhatjuk tehát, hogy az állapottér-modellkeret rugalmassága közelebb vitt bennünket a makrogazdasági egyensúly többdimenziós, soktényezős jellegének leírásához.

Miután a specifikációt áttekintettük, a következőkben a becslési eljárással foglalkozunk. A becslési módszer bemutatása előtt röviden ismertetjük a becsléshez felhasznált adatokat, illetve azok forrását.

\section{Felhasznált adatok}

A reál-GDP $\left(Y_{t}\right)$ esetén az előzőkhöz hasonlóan a KSH idősorát használtuk fel. A kibocsátási rés állapotegyenletében szereplö exogén változók közül az ipari eszközökre vonatkozó kapacitáskihasználtság szezonálisan igazított idősora az Eurostat Euroind-adatbázisából származik ${ }^{15}$ az EU15-re vonatkozó kibocsátásirésbecslés $\left(\hat{Y}_{t}^{E U}\right)$ pedig az Európai Bizottság AMECO (éves makroökonómiai adatbázis) adatbázisából. ${ }^{16}$

A munkanélküliségi rátát $\left(U_{t}\right) \mathrm{KSH}$-adatok alapján számítottuk a foglalkoztatottak és munkanélküliek számának szezonálisan kiigazított idősorai alapján. ${ }^{17}$

Az inflációs ráta $\left(\pi_{t}\right)$ esetében a maginfláció szezonálisan igazított értékével kalkuláltunk. Az adatok forrása ez esetben az MNB volt. A fogyasztási adatok

\footnotetext{
${ }^{15} \mathrm{http} / / /$ appsso.eurostat.ec.europa.eu/nui/show.do?dataset=ei_bsin_q_r2\&lang=en.

${ }^{16} \mathrm{http}$ ://ec.europa.eu/economy_finance/ameco/user/serie/SelectSerie.cfm.

${ }^{17} \mathrm{http}: / /$ www.ksh.hu/docs/hun/xstadat/xstadat_evkozi/e_qlf045.html.
} 
hiányában az éves infláció negyedéves adatsorát az MNB-től származó havi adatok mértani átlagolásával állítottuk elő. ${ }^{18}$

Végül, az áruk és szolgáltatások szezonálisan igazított egyenlegének GDP-arányos értékét $\left(X_{t}\right)$ ugyancsak MNB-adatok alapján számítottuk. ${ }^{19}$

A modellt az 1996 második negyedévétől 2016 negyedik negyedévéig terjedő - ezáltal 84 érvényes megfigyelést tartalmazó - mintán becsültük meg.

\section{Becslési módszer}

A specifikáció alapján egyértelműen látszik, hogy a több endogén változót tartalmazó modellben a becsülendő paraméterek száma is jelentősen nagyobb lesz az eddig látottakhoz képest. Alapvetően ez teszi szükségessé a paraméterek bayesi becslését, amivel a paraméterek identifikációját segítjük. A következőkben röviden áttekintjük a becslési eljárás lényegi lépéseit.

Jelölje ezek után $\theta$ a becsülendő paraméterek esetünkben $19 \times 1$-es oszlopvektorát, $\Gamma_{t}$ pedig a felhasznált adatok (megfigyelések) $84 \times 7$-es mátrixát. Ebben az esetben a loglikelihood függvény, az előzőben látottakhoz hasonlóan, a (26) szerint írható fel:

$L L\left(\boldsymbol{\Gamma}_{t} \mid \boldsymbol{\theta}\right)=-\frac{T}{2} \log (2 \pi)-\frac{1}{2} \sum_{t=1}^{T} \log \left(S_{t}\right)-\frac{1}{2} \sum_{t=1}^{T} \frac{z_{t}^{2}}{S_{t}}$.

Az állapottérmodell paramétereinek (mély paraméterek) bayesi becslése ugyanakkor már nem a klasszikus maximum likelihood módszer szerint történik: ez esetben a likelihood függvényt valamilyen alkalmasan választott prior sürüségfüggvénnyel súlyozzuk, s a becslés a paraméterek együttes posterior valószínűségi eloszlásának meghatározását, illetve annak bizonyos momentumokra kiterjedő feltérképezését jelenti. Ha $P\left(\boldsymbol{\theta} \mid \boldsymbol{\Gamma}_{t}\right)$ jelöli a posterior együttes sürüségfüggvényt, a probléma a (27) szerint írható fel:

$P\left(\boldsymbol{\theta} \mid \boldsymbol{\Gamma}_{t}\right)=\frac{L L(\boldsymbol{\Gamma} \mid \boldsymbol{\theta}) \Phi(\boldsymbol{\theta})}{p(\boldsymbol{\Gamma})}$,

ahol $L L(\boldsymbol{\Gamma} \mid \boldsymbol{\theta})$ a (26) egyenlettel definiált loglikelihood függvényt, $\Phi(\boldsymbol{\theta})$ pedig a paraméterek együttes prior sủrűségfüggvényét jelöli. Mivel belátható, hogy a perem likelihood értéke, $p(\boldsymbol{\Gamma})$, nem befolyásolja a keresett momentumok helyét, ezért a probléma a (28) szerint egyszerüsödik (DeJong-Chetan [2011] 354. o.):

$P\left(\boldsymbol{\theta} \mid \boldsymbol{\Gamma}_{t}\right) \propto L L\left(\boldsymbol{\Gamma}_{t} \mid \boldsymbol{\theta}\right) \Phi(\boldsymbol{\theta})$.

Ezek szerint a becslés során már csak azon paraméterkonfigurációk loglikelihoodértékét vesszük figyelembe, amelyek az együttes prior eloszlás alapján pozitív valószínüséggel elöfordulhatnak. Ezek alapján már az is látható, hogy a likelihood függvény alkalmas súlyozása miként teszi lehetővé előzetes elméleti tudásunk

\footnotetext{
${ }^{18} \mathrm{http} / / /$ www.mnb.hu/statisztika/statisztikai-adatok-informaciok/adatok-idosorok/vi-arak.

${ }^{19} \mathrm{http}: / / \mathrm{www} \cdot \mathrm{mnb} \cdot \mathrm{hu} / \mathrm{statisztika/statisztikai-adatok-informaciok/adatok-idosorok/viii-fizetesi-}$ merleg-kozvetlen-tokebefektetesek-kulfolddel-szembeni-allomanyok/fizetesi-merleg-kulfolddelszembeni-allomanyok/bpm6-modszertan-szerinti-adatok.
} 
felhasználását a becslési eljárásban. A ciklikus komponensek stacionaritására vonatkozó szokásos feltétel alapján $\beta_{11}, \beta_{21}, \beta_{31}, \beta_{41}$ paraméterek esetében $\beta$ marginális prior eloszlását feltételeztük.

A paraméterek prior eloszlásával kapcsolatos további feltevéseinket a Függelék F2. táblázatában közöljük. A marginális prior eloszlások meghatározásakor az irodalomban látott standardot követtük (Benes és szerzötársai [2010], Blagrave és szerzötársai [2015], Tóth [2011]). Ugyancsak az F2. táblázatban láthatjuk az általunk használt véletlenbolyongás-folyamat Metropolis-algoritmussal végzett (lásd Kehl-Várpalotai [2013]) szimulációs eredményét is. A szimuláció eredményét a marginális posterior eloszlások várható értékére, valamint azok 80 százalékos megbízhatósági tartományára (credible interval) vonatkozóan közöljük. ${ }^{20}$

\section{A modellbecslés eredménye}

A becslési eredmények értelmezésekor ezúttal is a becsült kibocsátási rés idősorára és az abból számolt potenciális növekedési ráták alakulására koncentrálunk. A többi endogén változó trend-rés-felbontását a Függelék F1. és F2. ábráin láthatjuk. Az 5. ábra a többváltozós kvázistrukturális modellünkben becsült kibocsátási rés értékét mutatja.

\section{5. ábra}

Többváltozós kvázistrukturális modellben becsült kibocsátási rés, 2002. I. negyedév-2016. IV. negyedév

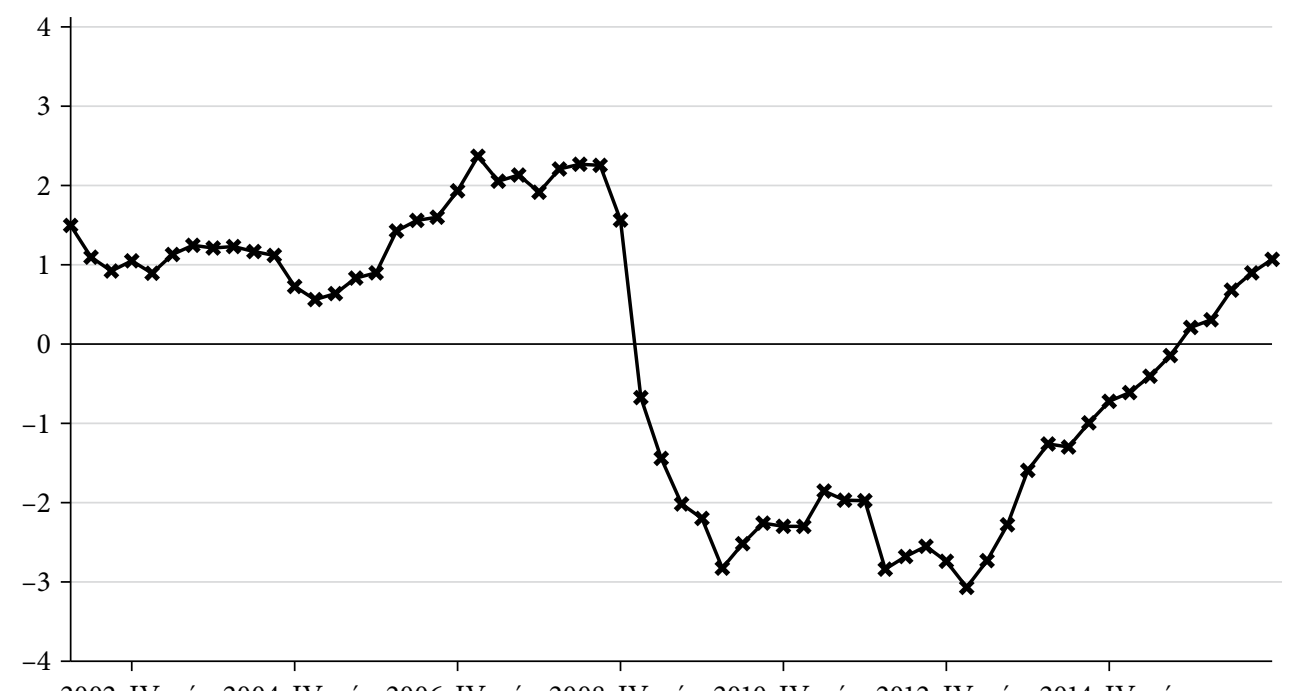

2002. IV. né. 2004. IV. né. 2006. IV. né. 2008. IV. né. 2010. IV. né. 2012. IV. né. 2014. IV. né.

Forrás: saját szerkesztés.

${ }^{20}$ A számításokat a Matlab IRIS Toolboxának függvényeivel végeztük el. A szimuláció során alkalmazott arwm algoritmus tízezer elemszámú Markov-láncot használt a posterior eloszlás feltérképezéséhez. Az eljárás 0,2326 értékủ elfogadási arányt eredményezett. 
Az 5. ábra alapján elmondható, hogy a becsült kibocsátási rés - különösen annak dinamikája - már jobban tükrözi a válság előtti időszakra vonatkozó kutatási hipotézisünket. Eszerint a pozitív kibocsátási rés elsősorban nem a válságot közvetlenül megelöző években (2005 elejétől 2007 elejéig) alakult ki, hanem már azt megelőzően. A válságot megelőző évek gazdaságpolitikája ez alapján csak annyiban hibáztatható, hogy a korábbról hozott pozitív rés mérséklésére érdemben már nem volt képes, jóllehet megállította a kedvezőtlen dinamikát.

Számunkra is kérdéses azonban, hogy minek tudható be a kibocsátási rés 2004 . végi jelentősebb korrekciója. Ezzel együtt úgy gondoljuk, hogy az 5. ábra már viszonylag jól tükrözi a fiskális alkoholizmus éveinek negatív gazdasági fejleményeit (Kopits [2006], [2008]). Abban bíztunk, hogy ha becslésünkben a közvetettadó-hatásaitól megtisztított árindexet (CPIVAI) használunk, a pozitív rés 2004. végi - saját várakozásainkkal is ellentétes - mérséklődése talán elkerülhető lett volna. Az eredmények azonban így sem mutattak érdemi változást.

Érdekes, hogy az 1. és a 3. ábrákon látottakhoz képest némiképp eltérő képet kapunk a 2011-2012. évi megtorpanásról is. Itt a válság utáni nagymértékü, negatív rés záródása eleve sokkal gyengébben látszik, következésképpen becslési eredményeinkben a 2011-2012. évi megtorpanás hatása is jóval mérsékeltebben jelenik meg.

A legfontosabb, amit az 5. ábrán láthatunk, hogy mostanra a válság utáni negatív rés már bezárult, sőt a minta végén (2016 utolsó negyedévére) a kibocsátási rés becsült értéke már pozitív (1,1 százalék) lett. A többi változó dekompozícióját szemléltető F1. és F2. ábra alapján ez az eredmény elsősorban azzal magyarázható, hogy a munkanélküliségi ráta ciklikus komponense 2016 végén negatív. Becslésünk szerint a munkanélküliség aktuális értéke alacsonyabb, mint annak trendértéke (F1. ábra). Természetesen a végponti bizonytalanság a többváltozós statisztikai szürők esetén is felmerül. Így a látens komponens valós értékétől elméletileg éppoly messze lehetünk, mint az 1. ábrán bemutatott egyszerü HP-simítással.

Az előzőkhöz hasonlóan lássuk, milyen ütemü potenciális növekedés adódik a becslés alapján! A 6. ábrán a kereszt jelölővel ellátott fekete szaggatott vonal mutatja a modellbecslés alapján számított potenciális növekedési pályát.

A 6. ábra szerint a becslés alapján kalkulált potenciális növekedési pálya sokkal inkább követi a tényleges növekedési ütemek idősorát, mintsem a HP-simítás alapján adódó potenciális növekedési pályát. Az ábra tanúsága szerint a magyar gazdaság éves növekedése csak három alkalommal tért el lényegesen az egyensúlyinak becsült potenciális növekedési ütemtől: 2006-ban, a 2008. évi válságot követően és 2014-ben. Akárcsak a 2. és az 5. ábra esetében, ezúttal is elmondható, hogy a becslési eredmények alapján a magyar gazdaság potenciális növekedése tartósan és jelentősen csökkent a 2008. évi válságot követően. A válság elötti, 4 százalék körüli egyensúlyi növekedési ütem alig fél százalékra esett vissza

A becslés eredménye alapján számított potenciális növekedési pálya nagyfokú volatilitását látva, felmerül az a kérdés, hogy vajon mennyiben vethetők össze ezek az értékek az előzőleg vizsgált modellek eredményeivel. Vegyük észre, hogy a potenciális növekedési pálya eddigiektől eltérő, nagyfokú volatilitását az eredményezi, 
6. ábra

A tényleges és a kvázistrukturális modellbecslés eredménye alapján számított éves potenciális növekedés, 2003. I. negyedév-2016. IV. negyedév

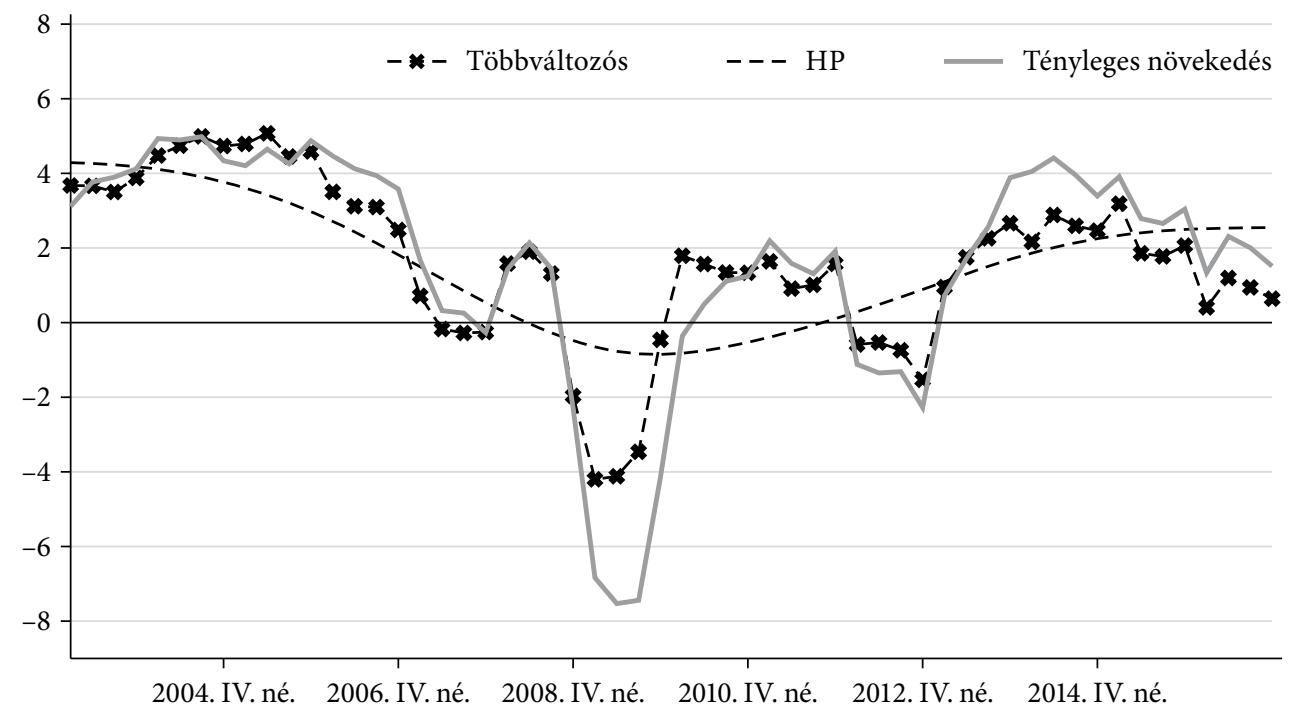

Forrás: saját szerkesztés.

hogy a többváltozós kvázistrukturális modell esetében nem alkalmaztuk a HPsimításnak megfelelő trend- és ciklusjellemzőket!

Mindezt az exogén magyarázó változók bevonásával készített trend-rés-felbontás esetében $\kappa$ értékének beállításával értük el. Ott arra voltunk kíváncsiak, hogy a $\lambda=1600$ paraméternek megfelelő átlagos ciklushossz mellett az addicionális exogén változók mennyiben változtatják meg a trend-rés-felbontás eredményét. Azt akartuk tehát látni, hogy különböző exogén változók bevonásával miként változik meg a hazai reálgazdasági ciklusról előzetesen kialakult kép. Már amennyiben feltételezhetjük, hogy a $\lambda=1600$ paraméterü HP-simítás eredménye ténylegesen a hazai reálgazdasági ciklus alakulását tükrözi. Ehhez képest a legutóbbi modellben lényegében az adatokra bíztuk a trend- és a ciklikus komponens relatív volatilitásának beállítását. Ennek eredményeként a 6. ábrán az eddig látottakhoz képest egy lényegesen volatilisebb potenciális növekedési pályát kaptunk, ami nyilván egy volatilisebb trenedet is feltételez. Ehhez a nagyobb volatilitású trendhez a reálgazdasági ciklusokhoz képest magasabb frekvenciájú, gyorsabb lefolyású, vagyis átlagosan rövidebb ciklusok társulnak. Ne feledjük azonban, hogy a reálgazdasági ciklus, még ha annak identifikációs nehézségeitől el is tekintünk, nem az egyetlen és nem feltétlenül a meghatározó mozgatója a hazai gazdaság konjunkturális ingadozásainak! Mindezek alapján úgy gondoljuk, hogy az eltérő trend- és ciklusjellemzőket feltételező modellek becslési eredményeinek összevetése megengedhető, sőt tanulságos lehet (Canova [1998a] 476. o., [1998b]).

Miután az eltérő trend- és ciklusjellemzőket alkalmazó modellek más és más trend-rés-dekompozíciókhoz vezetnek, a tényadatban levő információ más és más értelmezését kapjuk. A magyar gazdaság szempontjából különösen is fontos lehet 
a különbözö hosszúságú és típusú gazdasági ciklusok felmérése és dokumentálása, mivel az Egyesült Államok reálgazdasági ciklusához igazított HP-simítás alkalmazásával könnyen juthatunk a magyar makrogazdasági adatokban lévő információ téves értelmezéséhez (Agénor és szerzőtársai [2000]).

\section{Összehasonlító elemzés}

Tanulmányunk utolsó fejezetében az eddig látott saját modelljeink eredményét az MNB kibocsátásirés-becslésével hasonlítjuk össze. Azt vizsgáljuk, hogy az MNB becslése ( $M N B$ [2017]) mennyiben támasztja alá, illetve mennyiben kérdőjelezi meg korábbi megállapításainkat. A 7. ábrán tehát a ciklikus komponens értékére vonatkozó saját becsléseink eredménye mellett az MNB - tanulmányunk lezárásakor aktuális - becslését is feltüntettük.

\section{7. ábra}

A kibocsátási rés különböző modellekben becsült értékeinek összehasonlítása, 2002. I. negyedév-2016. IV. negyedév

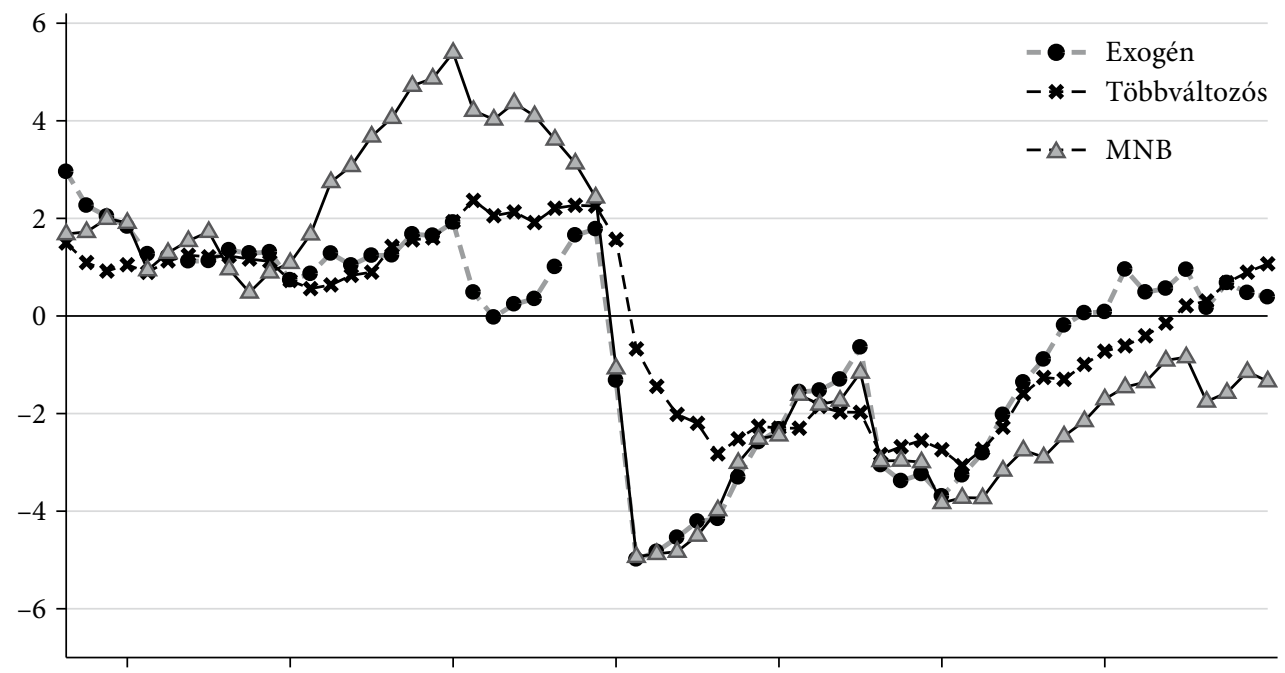

2002. IV. né. 2004. IV. né. 2006. IV. né. 2008. IV. né. 2010. IV. né. 2012. IV. né. 2014. IV. né.

Forrás: saját szerkesztés MNB [2017] alapján.

Az ábra tanúsága szerint az MNB becslése egyértelmüen megerősíti kutatási hipotézisünket: a pozitív rés elsősorban nem a válságot közvetlenül megelőző években alakult ki. Az MNB becslése alapján a kibocsátási rés 2004 elejétől kezdve gyors ütemben, tendenciózusan nőtt egészen 2006 végéig, amikor a megszorító intézkedések hatására megakadt a kedvezőtlen dinamika. Ennek megfelelően 2007 már kifejezetten gyenge év volt a gazdasági növekedés szempontjából, fél százalék körüli reálnövekedéssel. Kétségkívül volt tehát egyfajta fékezés a gazdaságpolitika részéről, de az már közvetlenül a válság előtt nem volt elegendő ahhoz, hogy érdemben csökkentse a hazai gazdaság 
sérülékenységét. Részben itt is érvényesek tehát az 5. ábra kapcsán tett megállapításaink. Míg azonban saját modellünk eredménye csak a kibocsátási rés dinamikáját tekintve tükrözte előzetes elgondolásainkat, addig az MNB becslése már szintben is megfelel a válság előtti időszakra vonatkozó intuíciónknak.

A 7. ábra alapján az is jól látható, hogy a 2008. évi válságot követő időszakra vonatkozó becslési eredmények jelentösen közelebb kerültek egymáshoz, ami arra utal, hogy a becslések modellválasztástól függö bizonytalansága valamelyest csökkent.

Ezzel együtt is eltérés látszik a ciklikus pozíció végponti értékelésében. Míg saját többváltozós modelljeinkben kismértékü pozitív rést becsültünk ( 0,4 és 1,1 százalék), addig az $M N B$ [2017] becslése a végpontban ugyancsak kismértékủ, ám negatív rést mutat (-1,3 százalék). Jóllehet a dinamikák alapvetően hasonlók, és a végponti eltérések sem nagyok, a látottak megint csak óvatosságra intenek bennünket. A negatív kibocsátási rés feltételezése mellett szól a (CPI alapú) infláció célérték alatti nagysága, valamint a folyó fizetési mérleg soha nem látott aktívuma. Ne feledjük azonban, hogy az említett változók értéke elsősorban nem a belső gazdasági működés vagy struktúra átalakulása következtében változott meg, hanem nagymértékü külső és belső sokkok hatására! A fogyasztóiár-infláció egyrészt a rezsicsökkentés inflációs várakozásokat is lehorgonyzó ereje miatt csökkent jelentősen. Másrészt pedig azért, mert deflációs periódus alakult ki a világgazdaságban. Vélhetően a folyó fizetési mérleg egyenlegének válságot követő erős korrekciója sem a hazai gazdaság hirtelen megnőtt versenyképességét tükrözi, sokkal inkább a fogyasztási kereslet drasztikus visszaesését. Az ilyen jelentős, egyszeri sokkok egy bizonyos mértékig természetesen minden egyes becslés megbízhatóságát gyengítik, ezért is különösen fontos a különböző modellekben kapott eredmények összehasonlító elemzése.

A kibocsátásirés-becslések összevetése után azt vizsgáljuk, hogy ezek alapján hogyan alakulnak a különböző éves potenciális növekedési pályák.

A 8. ábrán azt látjuk, hogy saját becsléseink és az MNB becslése alapján nagyon hasonló mértékủ potenciális növekedés adódik a vizsgált időszak elején és végén. 2004 elejétől kezdődően azonban lényegesen eltérő potenciális növekedési pályákat láthatunk. Az MNB becslése alapján a potenciális növekedés üteme már a 2004 közepétől 2005 közepéig tartó egyéves periódus alatt a felére csökkent. Ehhez képest saját modelljeinkben a potenciális növekedés jóval fokozatosabb lassulása figyelhetö meg, és a potenciális növekedés üteme csak 2005 végétől kezdve marad el lényegesen a reál-GDP tényleges növekedésétől (MNB [2017]).

A 7. ábra alapján mindez korántsem meglepő, hiszen a trend - vagyis a potenciális kibocsátás - növekedési ütemét a kibocsátási rés dinamikája határozza meg. A 2008 elejétől 2010 végéig terjedő időszakban ugyancsak markánsan eltérő eredményeket látunk. Az MNB [2017] becslése szerint a potenciális növekedés üteme 2008 közepén 3 százalék körül alakul. A gazdaság tehát a korábbi, 4 százalékos egyensúlyi növekedést biztosító pályához konvergál. Ezt a konvergenciát akasztja meg 2008 végén a pénzügyi válság begyürüzése, ami előbb a trend lassulásához, majd csökkenéséhez vezet. Ehhez képest saját becsléseinkből arra következtethetünk, hogy a magyar gazdaság potenciális növekedése már közvetlenül a 2008. évi válságot megelőzően is jócskán elmaradt az időszak eleji értékétől. Ezek szerint a hazai gazdaság 2008 harmadik negyedévében 


\section{8. ábra}

A különböző modellbecslések alapján kalkulált, éves potenciális növekedési pályák összehasonlítása, 2003. I. negyedév-2016. IV. negyedév

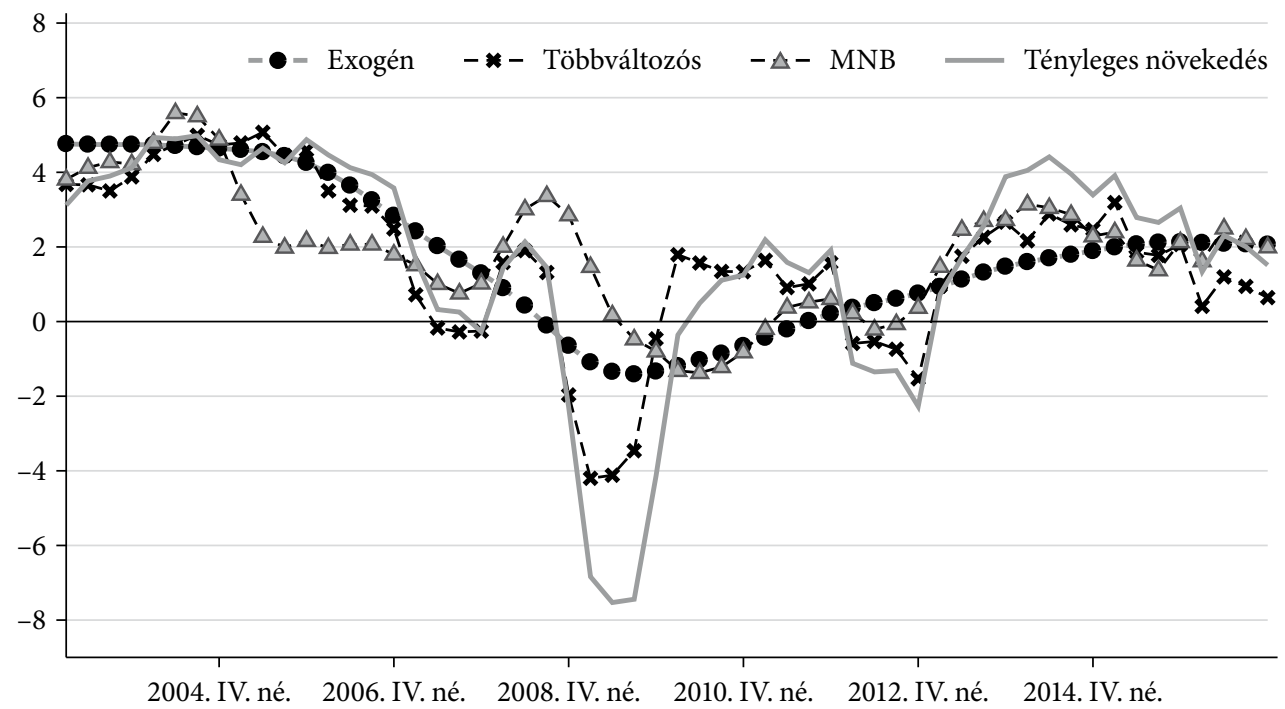

Forrás: saját szerkesztés $M N B$ [2017] alapján.

mutatott, az előző év azonos negyedévéhez mért, alig másfél százalékos reálnövekedése is megfelelt a potenciális növekedés ütemének (lásd kereszttel jelölt vonal), vagy felülmúlta (lásd körrel jelölt vonal). Eredményeink tehát azt sugallják, hogy a (potenciális) növekedés 2008 -at követő tartós visszaesése önmagában nem a válság következménye - 2008 utolsó negyedévében a pénzügyi válság már egy eleve alacsony növekedési kilátásokkal jellemezhető gazdaságot rendített meg.

A 8. ábra alapján azt mondhatjuk, hogy a becsült potenciális növekedési pályák 2012-től kezdve jelentősen közelednek egymáshoz: az MNB becslése, valamint az elöző fejezetben tárgyalt többváltozós modellünk becslése alapján adódó potenciális növekedési pályák különösen erős együttmozgása figyelhető meg 2012 és 2015 között. Összességében a mintaidőszak végét is ez a fajta konvergencia jellemezi, a becsült értékek kimondottan közel vannak egymáshoz. Az időszak végére az MNB [2017] becslése alapján majdnem 2 százalékos éves potenciális növekedési ütem adódik, ami gyakorlatilag megegyezik az exogén változókat szerepeltető modellünkben kapott értékkel. Többváltozós kvázistrukturális modellünk becslése alapján ennél alacsonyabb, 0,7 százalék körüli értéket kapunk a potenciális növekedés ütemére.

A potenciális növekedési pályák 2011-től megfigyelhető konvergenciája természetesen a kibocsátásirés-becslések előző ábrán látható közeledésével indokolható. Azt feltételeztük, hogy a becslések válságot követő konvergenciája a modellválasztástól függő bizonytalanság csökkenését tükrözi. Tisztán kell látnunk ugyanakkor, hogy ez az erősen optimista feltevés csak annyiban érvényes, amennyiben azt a tanulmányban prezentált empirikus eredmények alátámasztják. A vizsgált probléma természetét tekintve az agnosztikus szemlélet különösen is fontos, hiszen a trend- és a ciklikus 
komponens létezése is a modellező premisszáihoz kötött. Következésképpen a látens komponensek valós értékét akár végtelenül sok modell becslésével sem lehet meghatározni. Ezek szerint mindössze annyit tehetünk, hogy különböző modelljeink segítségével megpróbáljuk feltárni az ingadozásokért felelős gazdasági ciklusokat. E kísérlet hasznosságát tehát az adatokban levő információk valószerűbb értelmezése jelenti. Ebben a szemléletben fogalmazzuk meg tanulmányunk következtetéseit, amelyek reményeink szerint új kutatásokhoz és további szakmai vitához vezetnek.

A tanulmányban látott becslési eredmények alapján arra a következtetésre jutottunk, hogy a pozitív kibocsátási rés elsősorban nem a 2008. évi válságot közvetlenül megelőző években keletkezett, hanem a fiskális alkoholizmus korábbi évei során: elsősorban a 2004 elejétől 2006 végéig tartó időszakban. A ciklikus pozíció végponti értékelése szempontjából akár egy kismértékü pozitív, akár egy kismértékủ negatív rés mellett is érvelhetünk: a becslési eredmények $+1,1$ és $-1,3$ százalék között szóródnak. Ez alapján következtetésként adódik, hogy 2016 végére a korábbról hozott, jelentős mértékü negatív kibocsátási rés vélhetően bezárult. Megállapítottuk, hogy a kibocsátásirés-becslések értékelésekor fontos szempont, hogy a becsült rés dinamikája milyen potenciális növekedési pályát implikál. A különböző modellek összehasonlító elemzése alapján azt láttuk, hogy a 2008. évi válságot követően a magyar gazdaság potenciális növekedése tartósan és jelentősen csökkent: a 2003 elején látott 4 százalék körüli éves potenciális növekedési ütem közelítőleg a felére csökkent. Az eredményeket látva valószerűnek tűnhet a hiszteréziselmélet interpretációja. Ezek szerint a ciklikus komponens hatással lehet a trend szintjére, és annak meredekségét is tartósan érintheti (Bassi-Lang [2016], Göcke [2002], Setterfield [2009]). Ez utóbbi jelenség, az úgynevezett szuperhiszterézis (lásd Ball [2014]) a jövőbeli növekedési kilátásokra nézve is aggasztó lehet.

\section{Hivatkozások}

Aastveit, K. A.-Trovik, T. [2014]: Estimating the output gap in real time: A factor model approach. The Quarterly Review of Economics and Finance, Vol. 54. No. 2. 180-193. o. http://dx.doi.org/10.1016/j.qref.2013.09.003.

Abaligeti Gallusz-Németh Kristóf-Schepp Zoltán [2018]: Időben változó Taylorszabály a hazai monetáris politika jellemzésére. Közgazdasági Szemle, 56. évf. 1. sz. 24-43. o. http://dx.doi.org/10.18414/KSZ .2018.1.24.

Agénor, P. R.-McDermott, C. J.-Prasad, E. S. [2000]: Macroeconomic Fluctuations in Developing Countries: Some Stylized Facts. The World Bank Economic Review, Vol. 14. No. 2. 251-285. o. http://dx.doi.org/10.1093/wber/14.2.251.

BALL, L. [2009]: Hysteresis in Unemployment: Old and New Evidence. NBER Working Paper Series, No. 14818. http://dx.doi.org/10.3386/w14818.

BALL, L. [2014]: Long-term Damage from the Great Recession in OECD Countries. European Journal of Economics and Economic Policies: Intervention, Vol. 11. No. 2. 149-160. o. http:// dx.doi.org/10.4337/ejeep.2014.02.02. 
BAssi, F.-LANG, D. [2016]: Investment Hysteresis and Potential Output: A Post-KeynesianKaleckian agent-based approach. Economic Modelling, Vol. 52. Part A. 35-49. o. http:// dx.doi.org/10.1016/j.econmod.2015.06.022.

Benes, J.-Clinton, K.-Garcia-Saltos, R.-Johnson, M.-Laxton, D.-Manchev, P.Matheson, T. [2010]: Estimating Potential Output with a Multivariate Filter. IMF Working Papers, Vol. 2010. No. 285. http://dx.doi.org/10.5089/9781455210923.001.

Benk Szilárd-Jakab Zoltán-Vadas Gábor [2005]: Potential Output Estimations for Hungary: A Survey of Different Approaches. MNB Occasional Papers, No. 43. december, https://www.mnb.hu/letoltes/op-43.pdf.

Bernanke, B. S.-Gertler, M.-Gilchrist, S. [1999]: The financial accelerator in a quantitative business cycle framework. Megjelent: Taylor, J. B.-Woodford, M. (szerk.): Handbook of Macroeconomics, Vol. 1. Part C. 1341-1393. o. http://dx.doi.org/10.1016/s15740048(99)10034-X.

Blagrave, P.-Garcia-Saltos, R.-Laxton, D.-Zhang, F. [2015]: A Simple Multivariate Filter for Estimating Potential Output. IMF Working Papers, Vol. 2015. No. 79. http://dx.doi. org/10.5089/9781475565133.001.

Blanchard, O.-Summers, L. H. [1986]: Hysteresis and the European Unemployment Problem. NBER Working Paper Series, No. 1950. http://dx.doi.org/10.3386/w1950.

Borio, C.-Lowe, P. [2002]: Assessing the risk of banking crises. BIS Quarterly Review, december, 43-54. o. https://www.bis.org/publ/qtrpdf/r_qt0212e.pdf.

Borio, C.-Disyatat, P.-Juselius, M. [2014]: A Parsimonious Approach to Incorporating Economic Information in Measures of Potential Output. BIS Working Papers, No. 442. https://www.bis.org/publ/work442.htm.

Borio, C.-Disyatat, P.-Juselius, M. [2017]: Rethinking potential output: Embedding information about the financial cycle. Oxford Economic Papers, Vol. 69. No. 3. 655-677. o. https://doi.org/10.1093/oep/gpw063.

Canova, F. [1998a]: Detrending and business cycle facts. Journal of Monetary Economics, Vol. 41. No. 3. 475-512. o. http://dx.doi.org/10.1016/s0304-3932(98)00006-3.

Canova, F. [1998b]: Detrending and business cycle facts: A user's guide. Journal of Monetary Economics, Vol. 41. No. 3. 533-540. o. http://dx.doi.org/10.1016/s0304-3932(98)00008-7.

Canova, F. [2007]: Methods for Applied Macroeconomic Research. Princeton University Press, Princeton.

Darvas Zsolt-Simon András [2002]: A financiálisan fenntartható kibocsátás becslése a gazdaság nyitottságának felhasználásával. Közgazdasági Szemle, 49. évf. 5. sz. 361-376. o.

D’Auria, F.-Denis, C.-Havik, K.-McMorrow, K.-Planas, C.-Raciborski, R.-Röger, W.-Rossi, A. [2010]: The Production Function Methodology for Calculating Potential Growth Rates \& Output Gaps. European Economy, Economic Papers, 420. 1-105. o. http:// ec.europa.eu/economy_finance/publications/economic_paper/2014/pdf/ecp535_en.pdf.

DeJong, D. N.-Chetan, D. [2011]: Structural Macroeconometrics. 2. kiadás, Princeton University Press, Princeton.

Drehmann, M.-Borio, C.-Tsatsaronis, K. [2012]: Characterising the financial cycle: Don't lose sight of the medium-term! BIS Working Papers, No. 380. https://www.bis.org/publ/ work380.pdf.

Durbin, J.-Koopman, S. J. [2012]: Time Series Analysis by State Space Methods. 2. átdolgozott kiadás, Oxford Statistical Science Series, Oxford University Press.

Endrész Mariann-Pellényi Gábor-Rácz Olivér-Szörfi Béla-VÁrpalotai Viktor [2012]: Termelési függvény alapú potenciális kibocsátás Magyarországon. Kézirat. 
Frankel, J. A. [2011]: Monetary Policy in Emerging Markets. Megjelent: Friedman, B.-Woodford, M. (szerk.): Handbook of Monetary Economics. 3. kötet, 25. fejezet, 1439-1520. o. http://dx.doi.org/10.1016/b978-0-444-53454-5.00013-x.

GALÍ, J. [2015]: Monetary Policy, Inflation, and the Business Cycle: An Introduction to the New Keynesian Framework and Its Applications. 2. kiadás, Princeton University Press, Princeton. Giorno, C.-Richardson, P.-Roseveare, D.-van den Noord, P. [1995]: Estimating Potential Output, Output Gaps and Structural Budget Balances. OECD Economics Department Working Papers, No. 152. http://dx.doi.org/10.1787/533876774515.

Göcke, M. [2002]: Various Concepts of Hysteresis Applied in Economics. Journal of Economic Surveys, Vol. 16. No. 2. 167-188. o. http://dx.doi.org/10.1111/1467-6419.00163.

Greene, W. H. [2011]: Econometric Analysis. 7. kiadás, Pearson.

Hamilton, J. D. [2017]: Why you should never use the Hodrick-Prescott filter. Vox, június 22. https://voxeu.org/article/why-you-should-never-use-hodrick-prescott-filter.

Hajdu Oттó [2003]: Többváltozós statisztikai számítások. Központi Statisztikai Hivatal, Budapest.

Harvey, A. C. [1990]: Forecasting, Structural Time Series Models and the Kalman Filter. Cambridge University Press, Cambridge. http://dx.doi.org/10.1017/cbo9781107049994.

Harvey, A. C.-Jaeger, A. [1993]: Detrending, stylized facts and the business cycle. Journal of Applied Econometrics, Vol. 8. No. 3. 231-247. o. http://dx.doi.org/10.1002/ jae.3950080302.

Hodrick, R. J.-Prescott, E. C. [1997]: Postwar US business cycles: An empirical investigation. Journal of Money, Credit, and Banking, Vol. 29. No. 1. 1-16. o. http://dx.doi. org/10.2307/2953682.

Kehl Dániel-VÁrpalotai Viktor [2013]: A modern bayesi elemzések eszköztára és alkalmazás. Statisztikai Szemle, 91. évf. 10. sz. 971-992. o.

Konuki, T. [2010]: Estimating Potential Output and the Output Gap in Slovakia. Eastern European Economics, Vol. 48. No. 2. 39-55. o. http://dx.doi.org/10.2753/eee0012-8775480203.

Kopits György [2006]: The Sickest Men of Europe. The Wall Street Journal Europe, szeptember 21. 13. o.

KopITs GYöRgy [2008]: Saving Hungary's Finances. The Wall Street Journal Europe, december 4. 13-14. o.

Kuttner, K. N. [1994]: Estimating Potential Output as a Latent Variable. Journal of Business Economic Statistics, Vol. 12. No. 3. 361-368. o. http://dx.doi.org/10.2307/1392092.

LucAs, R. E. [1973]: Some International Evidence on Output and Inflation Tradeoffs. The American Economic Review, Vol. 63. No. 3.326-334. o. http://www.jstor.org/stable/1914364. Mankiw, N. G. [1999]: Makroökonómia. 3. kiadás. Osiris Kiadó, Budapest.

Mellár Tamás [2008]: Gazdaságpolitika makroszemléletben. PTE KTK, Pécs, http://ktk. pte.hu/sites/ktk.pte.hu/files/mellekletek/2017/05/201102_0.pdf.

Mellár TAmás [2011]: Néhány gondolat a makroegyensúly értelmezéséhez. KRTI Mühelytanulmányok, No. 2. PTE KTK, Pécs.

MNB [2017]: Inflációs jelentés. Magyar Nemzeti Bank, Budapest, március, https://www.mnb. hu/letoltes/hun-ir-1.pdf.

Nyman, C. [2010]: An indicator of resource utilisation. Sveriges Riksbank Economic Commentaries, No. 4. https://www.riksbank.se/globalassets/media/rapporter/ekonomiskakommentarer/fore-2017/engelska/2010/rap_ek_kom_nr4_101013_eng.pdf.

Obstfeld, M.-Rogoff, K. [1996]: Foundations of International Macroeconomics. The MIT Press. 
Okun, A. M. [1962]: Potential GNP: Its Measurement and Significance. American Statistical Association, Proceedings of the Business and Economics Statistics Section, 98-104. o.

Phillips, A. W. [1958]: The Relationship between Unemployment and the Rate of Change of Money Wages in the United Kingdom 1861-1957. Economica, Vol. 25. No. 100. 283-299. o. http://dx.doi.org/10.1111/j.1468-0335.1958.tb00003.x.

Pintér József [2007]: A spektrálanalízisről. Statisztikai Szemle, 85. évf. 2. sz. 130-156. o.

RÁCz Olıvér MıKLós [2012]: A gazdaság ciklikus pozíciójának megítélése bizalmi indikátorok segítségével. MNB-Szemle, június, 41-46. o. https://www.mnb.hu/letoltes/racz-1.pdf.

Setterfield, M. [2009]: Path Dependency, Hysteresis and Macrodynamics. Megjelent: Arestis, P.-Sawyer, M. (szerk.): Path Dependency and Macroeconomics. Palgrave Macmillan, London, 37-79. o. http://dx.doi.org/10.1057/9780230251090_2.

Taylor, J. B. [1993]: Discretion versus Policy Rules in Practice. Carnegie-Rochester Conference Series on Public Policy, Vol. 39. 195-214. o. http://dx.doi.org/10.1016/01672231(93)90009-1.

Tóth Máté Barnabás [2011]: Measuring the Cyclical Position of the Hungarian Economy: A Multivariate Unobserved Components Model. Kézirat.

VÁRY MikLós [2018]: A hiszterézis közgazdasági jelentőségéről postkeynesi szemléletben. Kézirat.

Világi BALÁzs [2012]: A fóáramhoz tartozó dinamikus makroökonómiai modellek empirikus értékelése. Kézirat, 18 o. http://cdn.blog.hu/el/eltecon/file/makrovita2012/ VilagiBalazs_makro_vita2_empirikus.pdf. 


\section{Függelék}

\section{F1. táblázat}

Matematikai változók listája

\begin{tabular}{ll}
\hline $\begin{array}{l}\text { Változó } \\
\text { jelölése }\end{array}$ & Változó leírása \\
\hline$Y_{t}$ & reálkibocsátás (tényidősor) \\
$\bar{Y}_{t}$ & a reálkibocsátás trendértéke, értelmezésünk szerint a potenciális kibocsátás \\
$y_{t}$ & a reálkibocsátás (természetes) logaritmusa \\
$\bar{y}_{t}$ & a potenciális kibocsátás logaritmusa \\
$\hat{Y}_{t}$ & a kibocsátási rés $t$-edik időszaki értéke \\
$\hat{C}_{t}$ & az ipari kapacitáskihasználtság teljes mintabeli átlagától vett eltérése (százalék) \\
$\hat{Y}_{t}^{E U}$ & az EU15-re vonatkozó kibocsátásirés-becslés \\
$U_{t}$ & munkanélküliségi ráta (tényidősor, százalék) \\
$\bar{U}_{t}$ & a munkanélküliségi ráta trendértéke \\
$\hat{U}_{t}$ & a munkanélküliség ciklikus komponense \\
$\pi_{t}$ & CPI-alapú éves infláció (tényidősor, százalék) \\
$\bar{\pi}_{t}$ & az infláció trendértéke \\
$\hat{\pi}_{t}$ & az infláció ciklikus komponense \\
$\pi_{t}^{T}$ & az MNB által meghirdetett inflációs cél \\
$X_{t}$ & a kereskedelmi mérleg GDP-arányos egyenlege (tényidősor, százalék) \\
$\bar{X}_{t}$ & a kereskedelmi mérleg trendértéke \\
$\hat{X}_{t}$ & a kereskedelmi mérleg ciklikus komponense \\
$\lambda$ & simínási paraméter a HP-szűrőben, ami a trend gyorsulását (az első differencia \\
\hline & megváltozását) bünteti \\
\hline
\end{tabular}

Forrás: saját szerkesztés. 
F2. táblázat

A modell paramétereinek marginális prior és posterior eloszlását jellemző fontosabb statisztikák értéke

\begin{tabular}{|c|c|c|c|c|c|}
\hline \multirow[t]{2}{*}{ Paraméter } & \multicolumn{3}{|c|}{ Prior } & \multicolumn{2}{|c|}{ Posterior } \\
\hline & várható érték & szórás & típusa & várható érték & $\begin{array}{c}10-90 \% \\
\text { megbízhatósági } \\
\text { tartomány }\end{array}$ \\
\hline$\alpha_{11}$ & 0,6 & 0,15 & normális & 0,634 & $0,467-0,813$ \\
\hline$\beta_{11}$ & 0,5 & 0,20 & béta & 0,578 & $0,429-0,731$ \\
\hline$\beta_{12}$ & 0,5 & 0,15 & normális & 0,147 & $0,095-0,207$ \\
\hline$\beta_{13}$ & 0,5 & 0,15 & normális & 0,255 & $0,155-0,347$ \\
\hline$\beta_{21}$ & 0,5 & 0,20 & béta & 0,684 & $0,488-0,823$ \\
\hline$\beta_{22}$ & 0,5 & 0,15 & normális & 0,266 & $0,169-0,384$ \\
\hline$\beta_{31}$ & 0,5 & 0,20 & béta & 0,811 & $0,733-0,882$ \\
\hline$\beta_{32}$ & 0,5 & 0,15 & normális & 0,178 & $0,087-0,293$ \\
\hline$\beta_{41}$ & 0,5 & 0,20 & béta & 0,466 & $0,268-0,697$ \\
\hline$\beta_{42}$ & 0,5 & 0,20 & normális & 0,159 & $0,056-0,279$ \\
\hline$\sigma_{\bar{Y}}$ & 0,01 & $\infty$ & inverz gamma & 0,044 & $0,040-0,048$ \\
\hline$\sigma_{\hat{Y}}$ & 0,15 & $\infty$ & inverz gamma & 0,017 & $0,012-0,023$ \\
\hline$\sigma_{\bar{U}}$ & 0,01 & $\infty$ & inverz gamma & 0,014 & $0,011-0,017$ \\
\hline$\sigma_{\hat{U}}$ & 0,15 & $\infty$ & inverz gamma & 0,011 & $0,010-0,013$ \\
\hline$\sigma_{\bar{\pi}}$ & 0,01 & $\infty$ & inverz gamma & 0,029 & $0,024-0,034$ \\
\hline$\sigma_{\hat{\pi}}$ & 0,15 & $\infty$ & inverz gamma & 0,038 & $0,032-0,045$ \\
\hline$\sigma_{\bar{X}}$ & 0,01 & $\infty$ & inverz gamma & 0,010 & $0,007-0,014$ \\
\hline$\sigma_{\hat{X}}$ & 0,25 & $\infty$ & inverz gamma & 0,022 & $0,018-0,027$ \\
\hline$\sigma_{\epsilon^{T}}$ & 0,25 & $\infty$ & inverz gamma & 0,017 & $0,012-0,021$ \\
\hline
\end{tabular}

Forrás: saját szerkesztés. 


\section{F1. ábra}

Többváltozós kvázistrukturális trend-rés-felbontás eredménye - I.

2002. I. negyedév-2016. IV. negyedév
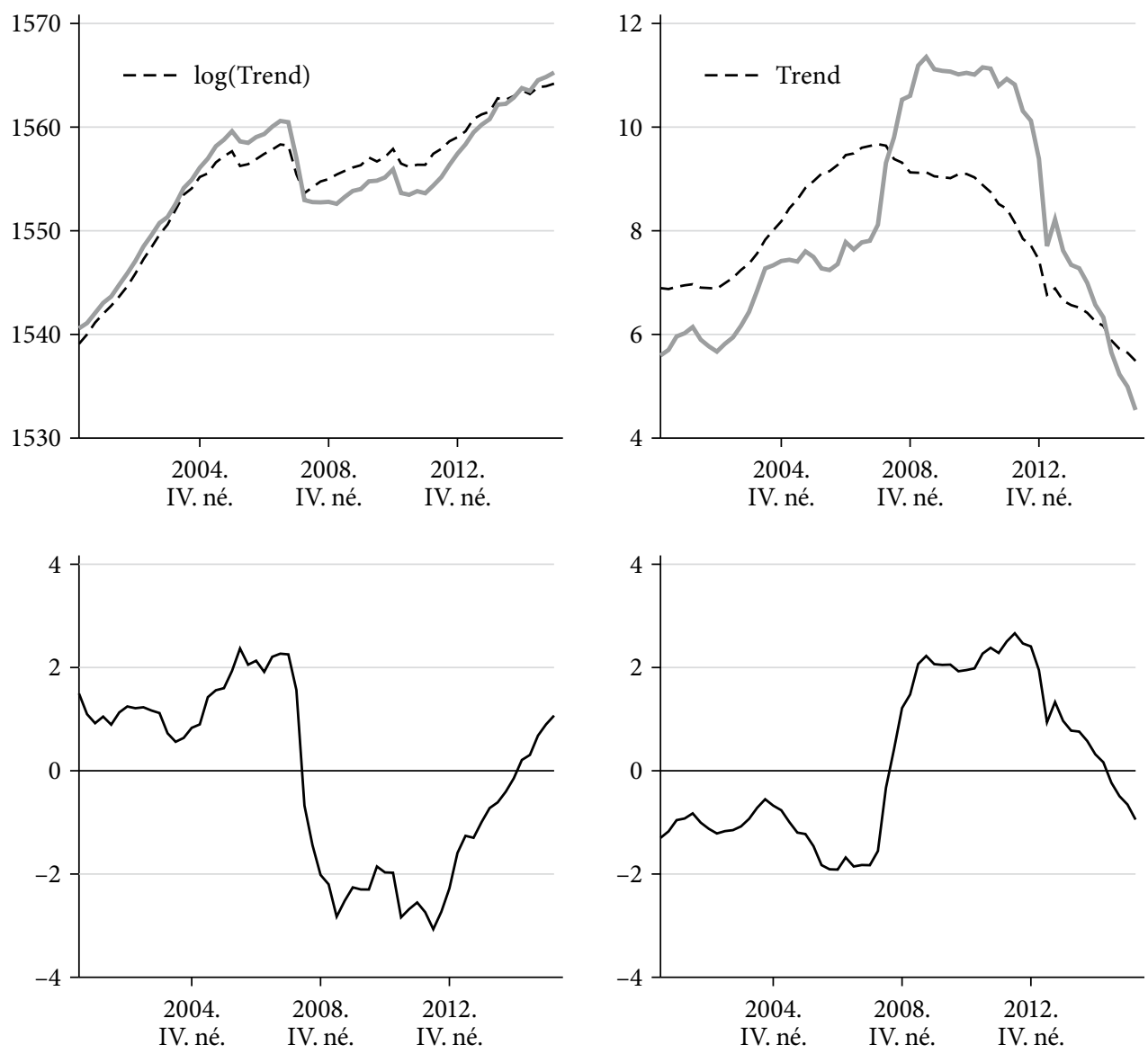

Forrás: saját szerkesztés. 


\section{F2. ábra}

Többváltozós kvázistrukturális trend-rés-felbontás eredménye - II.

2002. I. negyedév-2016. IV. negyedév
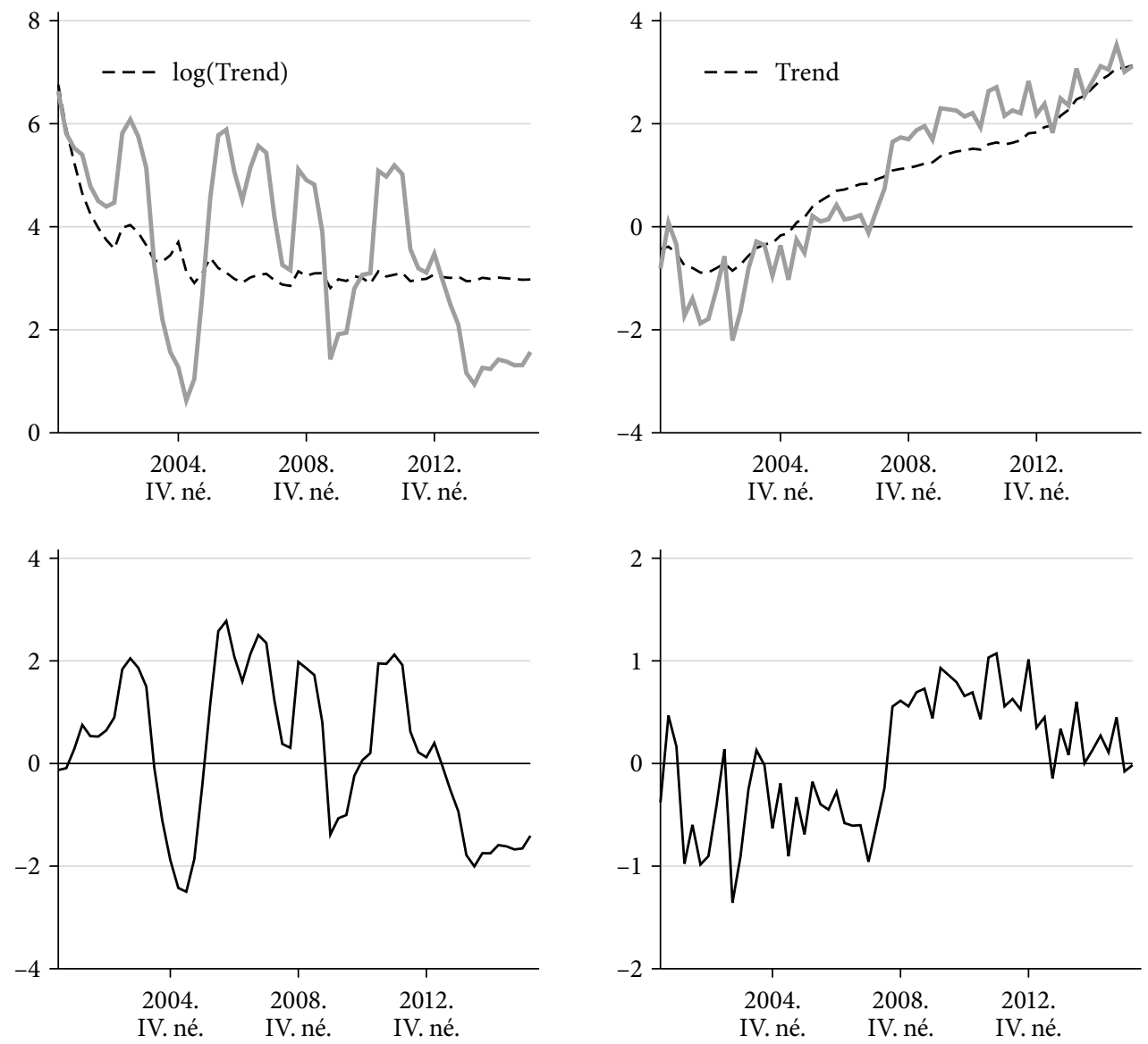

Forrás: saját szerkesztés. 